\title{
Article \\ Coexistent Heteroblastic Needles of Adult Pinus canariensis C.Sm. ex DC. in Buch Trees Differ Structurally and Physiologically
}

\author{
Beatriz Fernández-Marín ${ }^{1}, *\left(\mathbb{C}\right.$, Marcos Adrián Ruiz-Medina ${ }^{1}$, José Carlos Miranda ${ }^{2}(\mathbb{C}$ \\ and Águeda María González-Rodríguez ${ }^{1}$ \\ 1 Department of Botany, Ecology and Plant Physiology, University of La Laguna (ULL), \\ 38202 Tenerife, Spain; alu0101051642@ull.edu.es (M.A.R.-M.); aglerod@ull.edu.es (Á.M.G.-R.) \\ 2 Swiss Federal Institute for Forest Snow and Landscape Research WSL, \\ 8903 Birmensdorf, Switzerland; jc.miranda@upm.es \\ * Correspondence: bfernanm@ull.edu.es
}

Citation: Fernández-Marín, B.; Ruiz-Medina, M.A.; Miranda, J.C.; González-Rodríguez, Á.M. Coexistent Heteroblastic Needles of Adult Pinus canariensis C.Sm. ex DC. in Buch Trees Differ Structurally and

Physiologically. Forests 2021, 12, 341. https://doi.org/10.3390/f12030341

Received: 31 December 2020

Accepted: 2 March 2021

Published: 15 March 2021

Publisher's Note: MDPI stays neutral with regard to jurisdictional claims in published maps and institutional affiliations.

Copyright: (c) 2021 by the authors. Licensee MDPI, Basel, Switzerland. This article is an open access article distributed under the terms and conditions of the Creative Commons Attribution (CC BY) license (https:// creativecommons.org/licenses/by/ $4.0 /)$.

\begin{abstract}
Great variation in shape and size between primary (juvenile) and secondary (adult) needles, so-called leaf-heteroblasty, occurs in several Pinus species. Most of them loss primary needles during the juvenile-to-adult transition of the tree. An exception to this is Pinus canariensis (a Canary Islands endemism) in which basal resprouting twigs of adult trees frequently wear both primary and secondary needles. Taking advantage of this extraordinary study-case-species, we conducted an exhaustive comparison of both needle types through quantitative analyses of needle anatomy, photochemical performance, gas exchange, and resistance to extreme dehydration and to extreme needle temperature. We hypothesized that primary needles would show lower investment to leaf structure but higher photosynthetical efficiency. Primary needles had less stomatal density and thicker and less wettable cuticles. In cross section, primary needles showed smaller structural fraction (e.g., percent of hypodermis, endodermis and vascular tissue) and higher fraction of photosynthetic parenchyma. Significant differences between primary and secondary needles were not found in net carbon assimilation not in their leaf mass area values. Interestingly, secondary needles showed higher electron transport rate, and they were additionally much more efficient in retaining water under severe and controlled desiccant conditions. When subjected to extreme temperatures $\left(-10^{\circ}\right.$ to $+50{ }^{\circ} \mathrm{C}$ ), primary needles recovered better their photochemical efficiency than secondary needles, after $+46^{\circ}$ and $+48^{\circ} \mathrm{C}$ heat-shock treatments. Our results indicate that both needle types broaden the diversity of physiological responses against environmental constrains in basal twigs of adult $P$. canariensis trees. Considering that this is a fire-resistant and resprouting species, this advantage could be particularly useful after a drastic environmental change such a fire or a gap opening in the forest.
\end{abstract}

Keywords: Canary Islands; heteroblasty; leaf anatomy; Mediterranean climate; photoprotection; pine; primary needle; resprouting tree; secondary needle

\section{Introduction}

More than a century ago, the German botanist Karl Ritter von Goebel described the term "heteroblastic species" for the first time, to distinguish plants with abrupt changes in form and function occurring along their ontogeny from those in which no abrupt changes are perceptible [1]. Heteroblasty is thus defined as conspicuous morphological changes in stem structure, internode length or, typically, leaf form, size and arrangement throughout the lifecycle of some plants [2]. Although sometimes misused in the bibliography, and as clarified in recent reviews [2-4], leaf heteroblasty differs from heterophylly, which is a case of phenotypic plasticity exhibited as leaf form alteration in response to environmental conditions such as light intensity and quality, ambient temperature, and water availability $[3,4]$. 
Heteroblasty has evolved multiple times during plant evolution in different unrelated taxa [2,3], and some exceptional cases such as New Zealand flora particularly reach in heteroblastic plants (e.g., Pseudopanax crassifolius) [5], Acacia species, or the European Ivy (Hedera helix) have received deep scientific attention [2]. Another remarkable example is found within conifers as several species show a large heteroblastic modification between juvenile (primary) and adult (secondary) needles [6,7].

Foliar dimorphism has been studied in different genera such as Juniperus and Taxus [8,9], but most of the investigations, especially related to heteroblasty, have been carried out in species of Pinus: P. pinea, P. canariensis, P. halepensis, P. brutia and also P. pinaster [6,10-12]. Primary pine needles of those species are typically single and with different cross-sectional shape than secondary needles. The latter, normally arrange into multiple-needle brachyblasts, are longer, thicker and with higher dry mass per area (LMA) $[7,13]$. While for most Pinus species, primary needles are replaced by secondary needles during the first growth season, in several Mediterranean species such as P. halepensis, P. pinea and P. canariensis, primary needles are kept by seedlings for few years [14,15]. In the case of $P$. halepensis, this succession happens in several steps and only after the fourth year merely secondary needles are found [16]. The Canary Islands pine P. canariensis represents a remarkable case with extremely long-lasting juvenile stages and a prominent heteroblasty between primary and secondary needles $[15,17,18]$.

P. canariensis C.Sm. ex DC. in Buch [19] is a fire-resistant and drought-tolerant tree endemic to the Canary Islands $[20,21]$. The elevation range of this pine forest spreads between 1500-2000 m on the North and 900-2200 (2300) m a.s.l. on the South of the western Islands [22]. In Tenerife, this species is responsible for the treeline formation at 2000-2100 (locally 2400) m a.s.l. [23], which corresponds with a Mediterranean climate. The capability of $P$. canariensis stands to remobilize carbon reserves from woody organs allows for resprouting and crown regeneration, after extreme loss of foliage [24]. Newly resprouted shoots, after a perturbation, have only primary needles, in first place. The remarkable tolerance to drought in adult trees of P. canariensis is, on the other hand, linked to its capability to tap water from deep soil when growing under semi-arid Mediterranean climate [25]. Indeed, the Canary pine dedicates an important part of its resources in this phase to the construction of a powerful radical system very different from that of its fastgrowing juvenile congeners. In addition, scanning electron microscopy (SEM) studies have revealed, in secondary needles, deeply sunken stomata of an unusual type with an enlarged pre-stomatal cavity, which are very likely related to a strong resistance to water loss $[18,26]$. When developing under water stress, the secondary needles are additionally able to adapt their internal anatomy by rising the number of schlerenchymatic cells adjacent to the vascular bundles and by diminishing the ratio of assimilation parenchyma to vascular bundle [27]. The surface of primary needles, on the other hand, is completely covered by tubular wax crystals resulting in a glaucous appearance that increase protection against UV-radiation and also against high photon flux densities [28]. In agreement with all this previous observations, seedlings with secondary needles show better performance against drought stress than seedlings with primary needles [17].

While few morpho-anatomical characters $[18,28]$ and physiological traits such as the effect of drought $[7,29]$, the response to high levels of $\mathrm{CO}_{2}[29]$, and the effect of frost $[30,31]$ of the primary vs. the secondary needles, have been evaluated in a couple of conifers including several Pinus species, the functional understanding of this heteroblastic dimorphism is rather limited. Overall it seems to be a trade-off between needle toughness and photochemical efficiency, which is biased towards toughness in secondary needles and towards higher photosynthetical efficiency in primary needles. Nevertheless, some evidences are contradictory and inconclusive. In addition, most previous studies have been performed in seedlings and/or immature young trees [30]. In this scenario, P. canariensis provides a unique case-study as primary needles constitute the photosynthetic organs not only in immature trees but also in adult tree resprouts after disturbances. Moreover, gaining knowledge on primary needle anatomy and physiology will improve our understanding 
on the capacity of this species to endure forest fires that are expected to increase their frequency in future Mediterranean climate conditions [32]. P. canariensis is one of the five in the genus known to resprout in adult stages together with P. rigida, P. serotina, P. leiophylla and $P$. patula $[20,33,34]$. In addition, the frequent resprouting basal twigs on low density stand individuals provided us the opportunity to compare same-age primary vs. secondary needles from 60-70 y old trees, in morpho-anatomical and physiological terms. All things considered, we aimed at elucidating whether and how morpho-anatomical differences may relate with photosynthetical performance and response to abiotic stress in secondary vs. primary coexistent needles of adult P. canariensis trees. Specifically, we wanted to (i) characterise morpho-anatomical traits, (ii) compare photosynthetic performance and its acclimation at day/seasonal time-scales, (iii) assess tolerance to severe dehydration, and (iv) evaluate tolerance to extreme temperatures of primary vs. coexistent secondary needles.

\section{Materials and Methods}

\subsection{Plant Material and Experimental Design}

This study was conducted in a treeline pine forest located in Las Cañadas of Teide National Park, Tenerife $\left(28^{\circ} 18^{\prime} 21.5^{\prime \prime} \mathrm{N}, 16^{\circ} 34^{\prime} 5.8^{\prime \prime} \mathrm{W}\right.$; Canary Islands, Spain). The study plot was at an elevation of $2070 \mathrm{~m}$ above sea level, where the dominant species is Pinus canariensis C.Sm. ex DC. in Buch., with an almost non-existent understory. The site is characterized by a semiarid Mediterranean climate with a mean annual precipitation of $368 \mathrm{~mm}$, where the drought period lasts from June to August, and precipitation is concentrated in late autumn and winter. The drought period coincides with the highest temperatures, while the minimum temperatures (subzero) are reached in the rainy period [21]. At the time of study (2019-2020) the trees were 60-70 years old. All measurements were conducted in individual twigs containing same year juvenile and adult needles (Figure 1), from ten selected trees. Most measurements were conducted either in autumn (November 2019, 2020) or summer (July 2020) (specific dates, and replicates per each type of measurement are depicted in Table S1). All needles measured were, approximately 1 year old. A single experiment (to check for frost tolerance) was conducted with spring needles (April 2019). When measurements were not directly performed in the field, twigs containing both types of needles were placed in hermetically sealed bags at $100 \%$ relative humidity, to prevent desiccation, transferred to the laboratory and incubated in darkness for $16 \mathrm{~h}$ before experiments.

\subsection{Leaf Anatomy}

For morpho-anatomical analyses a total of 20 needles per type were studied: 5 twigs were selected (from a different tree each). From each branch, four representative primary and four representative secondary needles were taken. Several parameters were measured on intact needles or branches (Table 1). Finally, one cross-section per needle was analysed. A 2-3 mm length piece of the middle part of the needles was cut and fixed in FAA (100 mL $\mathrm{FAA}=90 \mathrm{~mL} 70 \%$ ethanol $+5 \mathrm{~mL}$ acetic acid $96 \%+5 \mathrm{~mL}$ formaldehyde solution $37 \%$ ) for $48 \mathrm{~h}$. Samples were then rinsed with water and dehydrated through a series of $50 \%$, $70 \%, 85 \%, 96 \%$ and $100 \%$ ethanol. Needle pieces were then embedded in paraffin and sectioned at $6 \mu \mathrm{m}$ thickness with a rotary microtome MT.5505 (PCE Iberica S.L., Albacete, Spain). All sections were dewaxed by a xylene series, stained with safranin and counterstained with fast green (Gerlach, 1984). Finally, needle samples were preserved using the EUKITT mounting medium (O. Kindler $\mathrm{GmbH})$. All sections were examined with a light microscope (AmScope, CA, USA), coupled with a Dual Pixel camera (SM-G955, Samsung). Image analysis was conducted in ImageJ 1.5 software (Wayne Rasband, National Institutes of Health, Bethesda, MD, USA). The number of hypodermis cell layers was measured considering the entire perimeter of the leaf (Figures 2 and 3). Stomatal density $\left(\mathrm{N}^{\mathrm{o}} \mathrm{mm}^{-2}\right)$ was assessed under the microscope on a square of $1 \mathrm{~mm}$ side carefully marked over the central part of each needle. All measured features are described on Table 2. 

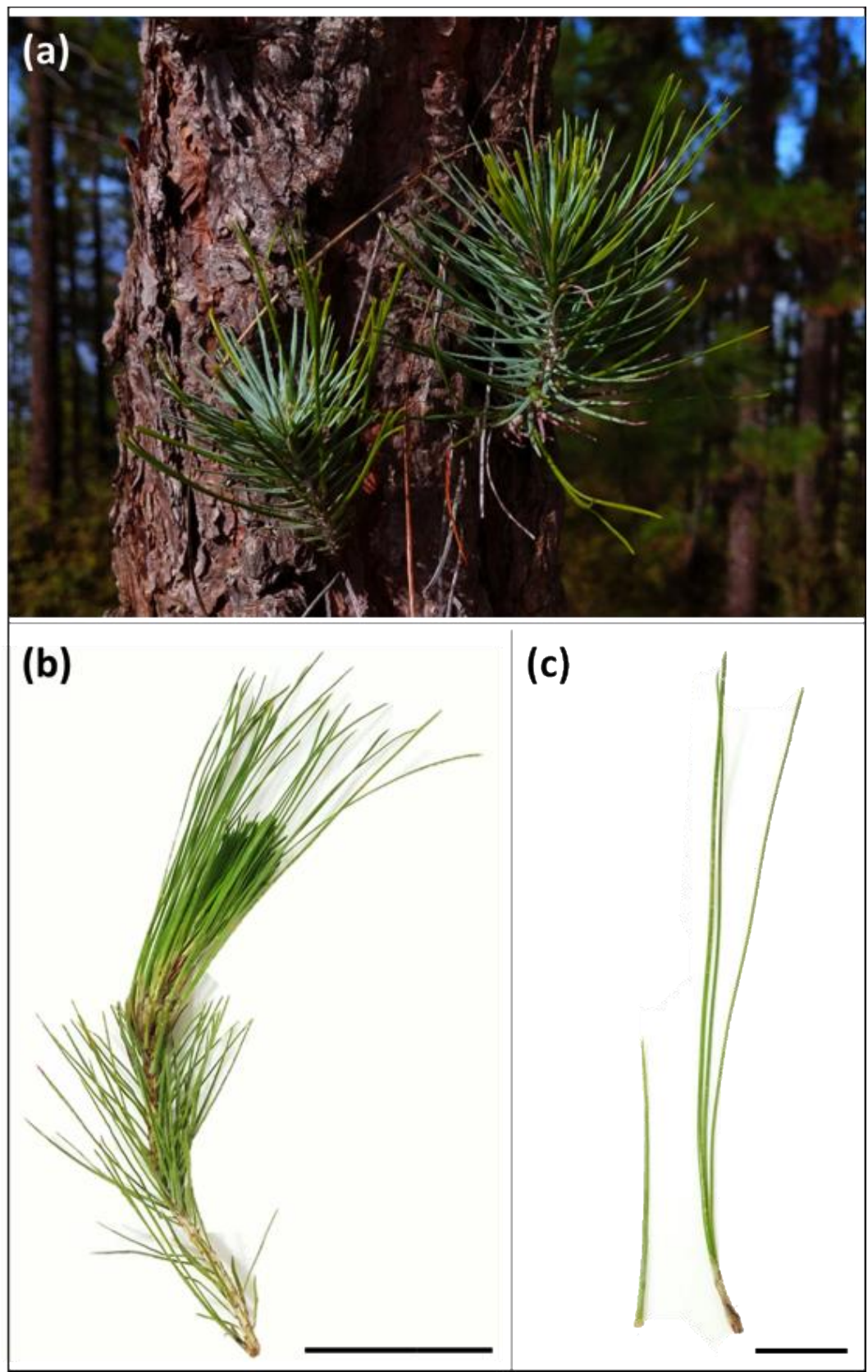

Figure 1. General aspect of the studied needles: (a) Intact resprouting twigs; (b) Detail of a detached twig with primary needles in the base and secondary needles in the tip. (c) Detail of a detached primary needle (left) and a brachyblast containing three secondary needles (right). Scale bars are: (b) $5 \mathrm{~cm}$; (c) $2 \mathrm{~cm}$. 


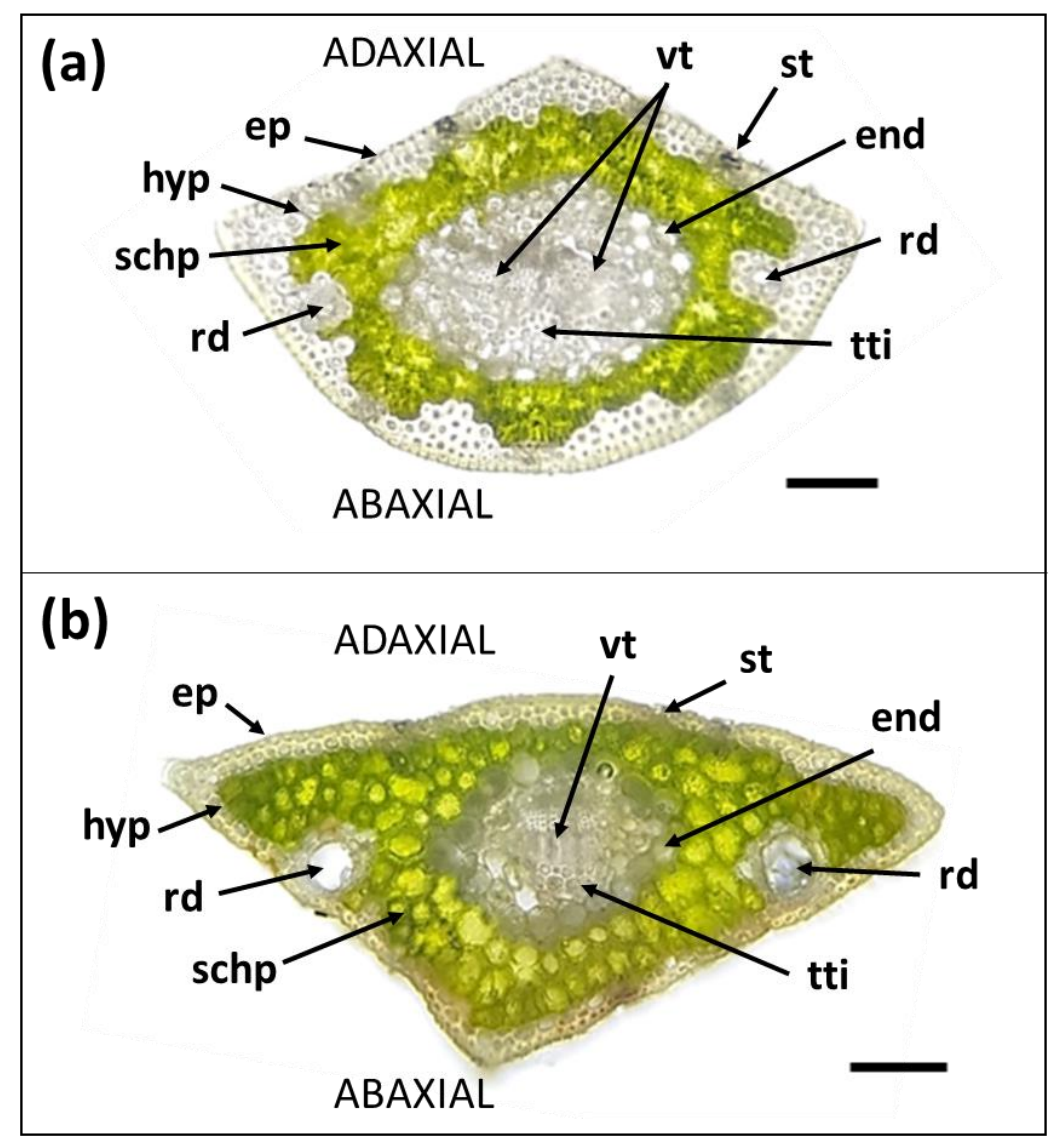

Figure 2. Fresh cross-sections of Pinus canariensis needles. (a) secondary (adult) needle. (b) primary (juvenile) needle. Abbreviations: end, endodermis; ep, epidermis; hyp, hypodermis; rd, resin duct; schp, spongy chlorophyll parenchyma; st, stomata; tti, transfusion tissue; vt, vascular tissue. Scale bars are $50 \mu \mathrm{m}$.

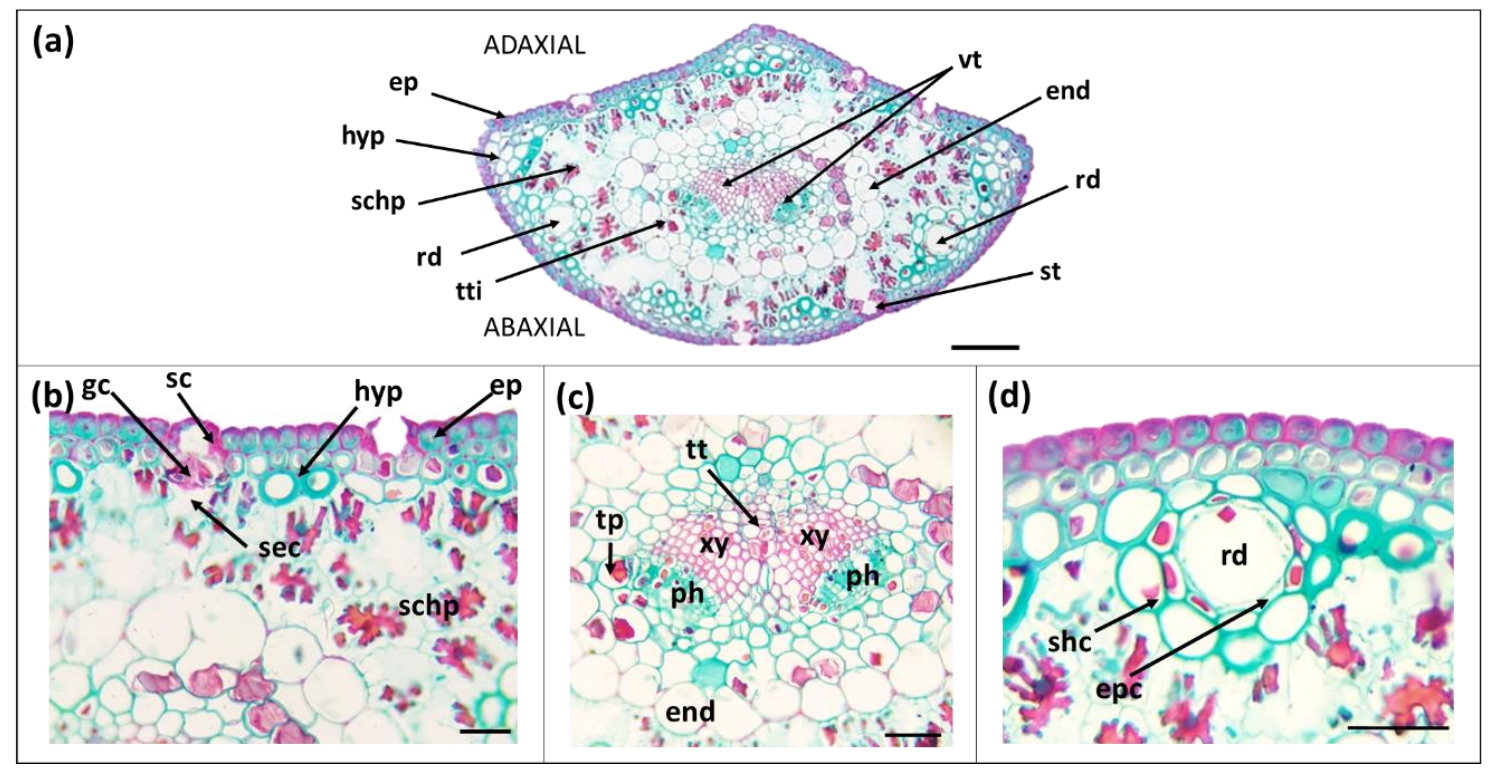

Figure 3. Stained cross-sections of Pinus canariensis secondary (adult) needles. (a) Whole view of the needle cross-section. (b) Detail of the stomata and outer tissues of the needle. (c) Detail of the vascular bundle and all the conductive elements. (d) Detail of a resin duct. Abbreviations: end, endodermis; ep, epidermis; epc, epithelial cells; gc, guard cells; hyp, hypodermis; ph, phloem; rd, resin duct; sc, subsidiary cells; schp, spongy chlorophyll parenchyma; sec, substomatal chamber; shc, sheath cell; st, stomata; tp, transfusion parenchyma; $\mathrm{tt}$, transfusion tracheid; tti, transfusion tissue; $\mathrm{vt}$, vascular tissue; xy, xylem. Scale bars (a), $50 \mu \mathrm{m},(\mathbf{b}-\mathbf{d}), 20 \mu \mathrm{m}$. Safranin—fast green staining. 
Table 1. Morphological traits of secondary (adult) and primary (juvenile) needles in P. canariensis. Values are mean $\pm \mathrm{SE}$ ( $n=20$, except for leaf water content, dry weight/fresh weight (DW/FW) ratio and leaf mas area (LMA) where $n=9$, and contact angle (CA) where $n=16-20)$. Values highlighted in bold with different letters depict significant differences between secondary (adult) and primary (juvenile) needles $(p<0.05)$.

\begin{tabular}{|c|c|c|c|}
\hline Needle Part & Parameter & Secondary Needles & Primary Needles \\
\hline \multirow[t]{9}{*}{ General traits } & Needles per brachyblast $\left(\mathrm{N}^{\circ}\right)$ & 3 & 1 \\
\hline & $\begin{array}{l}\text { Internode length among } \\
\text { needle insertions / brachyblasts }(\mathrm{cm})\end{array}$ & $0.13 \pm 0.01^{b}$ & $0.22 \pm 0.01^{a}$ \\
\hline & Leaf length $(\mathrm{cm})$ & $11.5 \pm 0.4^{\mathrm{b}}$ & $4.36 \pm 0.10^{\mathrm{a}}$ \\
\hline & Leaf width (mm) & $0.408 \pm 0.002^{b}$ & $0.573 \pm 0.006^{a}$ \\
\hline & Leaf thickness $(\mathrm{mm})$ & $0.231 \pm 0.002^{\mathrm{a}}$ & $0.232 \pm 0.001^{\mathrm{a}}$ \\
\hline & Leaf water content at turgor $\left(\mathrm{gH}_{2} \mathrm{O} \mathrm{g}^{-1} \mathrm{DW}\right)$ & $1.39 \pm 0.03^{\mathrm{a}}$ & $1.36 \pm 0.04^{\mathrm{a}}$ \\
\hline & Leaf $\mathrm{DW} / \mathrm{FW}$ ratio & $0.418 \pm 0.005^{\mathrm{a}}$ & $0.425 \pm 0.008^{\mathrm{a}}$ \\
\hline & $\operatorname{LMA}\left(\mathrm{g} \mathrm{m}^{-2}\right)$ & $181.7 \pm 5.9^{\mathrm{a}}$ & $164.7 \pm 5.7^{\mathrm{a}}$ \\
\hline & $\mathrm{CA}\left({ }^{\circ}\right)$ & $114.2 \pm 2.7^{b}$ & $137.8 \pm 2.1^{a}$ \\
\hline \multirow[t]{4}{*}{ Stomata } & Number of rows on adaxial surface $\left(\mathrm{N}^{\circ}\right)$ & 3 to 5 & 2 to 5 \\
\hline & Number of rows on abaxial surface $\left(\mathrm{N}^{\mathrm{o}}\right)$ & 4 to 5 & 2 to 4 \\
\hline & Density on the adaxial surface $\left(\mathrm{N}^{\mathrm{o}} \mathrm{mm}^{-2}\right)$ & $39.8 \pm 1.2^{\mathrm{a}}$ & $41.5 \pm 1.7^{\mathrm{a}}$ \\
\hline & Density on the abaxial surface $\left(\mathrm{N}^{\mathrm{o}} \mathrm{mm}^{-2}\right)$ & $51.4 \pm 1.4^{b}$ & $36.9 \pm 1.9^{a}$ \\
\hline
\end{tabular}

Table 2. Anatomical traits in secondary (adult) and primary (juvenile) needles estimated under the light microscope in stained cross-sections. Values are mean \pm SE $(n=20)$. Units are specified in brackets for each parameter. Percentages refer to total cross-section area. Values highlighted in bold with different letters depict significant differences between secondary (adult) and primary (juvenile) needles $(p<0.05)$.

\begin{tabular}{|c|c|c|c|}
\hline Needle Part & Parameter & Secondary Needles & Primary Needles \\
\hline Whole needle & Cross-section area $\left(\mathrm{cm}^{2}\right)$ & $0.32 \pm 0.01^{b}$ & $0.25 \pm 0.01^{a}$ \\
\hline Cuticle & Thickness (adaxial side) $(\mu \mathrm{m})$ & $0.532 \pm 0.034^{b}$ & $0.906 \pm 0.058^{a}$ \\
\hline Hypodermis & $\begin{array}{c}\text { Layers }\left(\mathrm{N}^{\mathrm{o}}\right) \\
\text { Cells diameter }(\mu \mathrm{m}) \\
\text { Hypodermis }(\%)\end{array}$ & $\begin{array}{c}1 \text { to } 5 \\
6.13 \pm 0.18^{b} \\
22.9 \pm 0.4^{b}\end{array}$ & $\begin{array}{c}1 \text { to } 2 \\
9.20 \pm 0.40^{a} \\
16.5 \pm 0.2^{a}\end{array}$ \\
\hline Mesophyll & Spongy parenchyma (\%) & $33.9 \pm 0.4^{b}$ & $46.9 \pm 0.4^{a}$ \\
\hline Endodermis & Cell diameter $(\mu \mathrm{m})$ & $16.9 \pm 0.5^{b}$ & $21.1 \pm 0.9^{a}$ \\
\hline Vascular bundle & $\begin{array}{c}\text { Transfusion tissue }(\%) \\
\text { Vascular bundles }\left(\mathrm{N}^{\circ}\right) \\
\text { Vascular tissue }(\%) \\
\text { Xylem }(\%) \\
\text { Phloem }(\%)\end{array}$ & $\begin{array}{c}8.63 \pm 0.12^{b} \\
2 \\
4.63 \pm 0.07^{b} \\
3.28 \pm 0.06^{b} \\
1.35 \pm 0.03^{b}\end{array}$ & $\begin{array}{c}13.9 \pm 0.2^{a} \\
1 \\
2.14 \pm 0.03^{a} \\
1.34 \pm 0.02^{a} \\
0.806 \pm 0.014^{a}\end{array}$ \\
\hline Resin ducts & $\begin{array}{c}\text { Number per needle } \\
\text { Position } \\
\text { Resin ducts lumen area }\left(\mu \mathrm{m}^{2}\right) \\
\text { Resin ducts diameter }(\mu \mathrm{m}) \\
\text { Sheath-cell layers }\left(\mathrm{N}^{\circ}\right) \\
\text { Sheath-cell diameter }(\mu \mathrm{m})\end{array}$ & $\begin{array}{c}2 \\
\text { under hypodermis } \\
327 \pm 9^{\mathrm{b}} \\
\mathbf{4 0 . 5} \pm \mathbf{0 . 7 ^ { \mathrm { b } }} \\
\mathbf{2} \\
\mathbf{9 . 4 7 \pm 0 . 5 4 ^ { \mathrm { b } }}\end{array}$ & $\begin{array}{c}2 \\
\text { under hypodermis } \\
669 \pm 10^{\mathrm{a}} \\
47.7 \pm 0.7^{\mathrm{a}} \\
\mathbf{1} \\
12.97 \pm 0.38^{\mathrm{a}}\end{array}$ \\
\hline
\end{tabular}

\subsection{Chlorophyll Fluorescence Analyses}

Rapid Light Curves (RLC) were developed in situ with a portable modulated fluorometer (miniPAM, Walz GmbH, Effeltrich, Germany). Measurements were carried out in four healthy needles exposed to light intensity below $40 \mu \mathrm{mol} \mathrm{m}{ }^{-2} \mathrm{~s}^{-1}$ in the early morning. Then, nine increasing light intensities (from 10 to $1856 \mu \mathrm{mol} \mathrm{m}^{-2} \mathrm{~s}^{-1}$ ) were continuously applied on the naturally exposed surface of needles at intervals of $15 \mathrm{~s}$. After each interval, 
a saturation pulse was applied in order to determinate steady fluorescence value under illumination $\left(\mathrm{F}^{\prime}\right)$ and maximum fluorescence value under illumination $\left(\mathrm{Fm}^{\prime}\right)$, in order to calculate $\varphi$ PSII, and the electron transport rate (ETR), by the following formula [35-37]:

$$
\mathrm{ETR}=\varphi \mathrm{PSII} \times \mathrm{PPFD} \times 0.5 \times 0.84
$$

where $\varphi$ PSII is the photochemical yield of the PSII in the light, PPFD is the photosynthetic photon flux density incident on the leaf, 0.5 is a factor that assume equal excitation of both PSII and PSI, and 0.84 takes into account that only a fraction of incident light is really absorbed by photosystems.

The analysis of ETR/PPFD curve allows the calculation of the maximum ETR (ETR max $\left._{\text {ax }}\right)$ and the maximum PPFD at which the maximum ETR is maintained ( $\left.P P \mathrm{D}_{\text {sat }}\right)$. Both parameters are derived from a polynomial equation adjusted to the final stages of the ETR curve (Solver, Microsoft Excel, 2010). Following [38], the apparent quantum efficiency (AQE, potentially transported $\mu$ mol electrons $\mathrm{m}^{-2} \mathrm{~s}^{-1}$ per each absorbed $\mu \mathrm{mol}$ photons $\mathrm{m}^{-2} \mathrm{~s}^{-1}$ ) was calculated directly by averaging $\varphi$ PSII 0.5 at lower irradiances. The minimum absorbed saturating photosynthetic photon flux density $\left(\mathrm{EK}, \mu \mathrm{mol} \mathrm{m} \mathrm{m}^{-2} \mathrm{~s}^{-1}\right)$ was calculated as $\mathrm{ETR}_{\max } / \mathrm{AQE}[39]$.

\subsection{Gas Exchange Measurements}

Net $\mathrm{CO}_{2}$ assimilation $\left(A_{N}\right)$ and stomatal conductance $\left(g_{\mathrm{s}}\right)$ were measured, at approximately 9.00 to $13.00 \mathrm{~h}$ solar time, with a portable photosynthesis system (LI-6400, Li-Cor, Lincoln, NE, USA) equipped with a $2 \mathrm{~cm}^{2}$ leaf chamber fluorometer (6400-40, Li-Cor). Because this chamber is designated for flat leaves, needles were spread over the chamber forming a one-needle-deep layer (as previously described by Niinemets et al., e.g., [40]). The chamber was completely filled with needles preventing overlapping and wholes between needles. Healthy needles were measured at $400 \mu \mathrm{mol} \mathrm{CO}_{2} \mathrm{~mol}^{-1}$ air (controlled with the $6400-01 \mathrm{CO}_{2}$ mixer), $1200 \mu \mathrm{mol}$ photons $\mathrm{m}^{-2} \mathrm{~s}^{-1}$ of PPFD [41], ambient relative humidity and ambient temperature (using the cuvette cooler to avoid overheating during measurements).

\subsection{Analysis of Photosynthetic Pigments}

Chlorophylls and carotenoids were quantified in needles sampled the same days as gas exchange and fluorescence measurements were performed. The middle part of the needles (both types) was collected in the field at noon, frozen in liquid $\mathrm{N}_{2}$ and stored at $-80{ }^{\circ} \mathrm{C}$ until analysis. Additional branches were maintained under an atmosphere saturated with $\mathrm{H}_{2} \mathrm{O}$, in darkness and at $+20^{\circ} \mathrm{C}$ overnight (for approximately $16 \mathrm{~h}$ ) in the laboratory. Both needle types were taken the next day and accounted as artificial (darkacclimated) conditions and also frozen in liquid $\mathrm{N}_{2}$. Samples were pulverized in a mortar with liquid nitrogen and extracted with $100 \%$ acetone with $\mathrm{CaCO}_{3}$ in order to avoid acid traces that modify the pigment composition. They were centrifuged for $15 \mathrm{~min}$ at $4{ }^{\circ} \mathrm{C}$ and syringe-filtered through $0.45 \mu \mathrm{m}$ Millipore filter. Pigments were quantified with a double beam spectrophotometer (Shimadzu, UV-160 A) following the method proposed by Lichtenthaler (1987) [42].

\subsection{Estimation of Needle Wettability through Contact Angle}

The contact angle (CA) of droplets of distilled water was measured over the surface of the needles, following [43] with small modifications. Briefly, sessile droplets of $5 \mu \mathrm{L}$ were placed on the adaxial side of the central part of each needle. Measurements were conducted with a video-based Optical Contact Angle measuring instrument (OCA 15EC, from DataPhysics Instruments $\mathrm{GmbH}$, Filderstadt, Germany). The contact angle was estimated, at one second after contact, with the SCA software (DataPhysics Instruments $\mathrm{GmbH}$, Filderstadt, Germany) for optical contact angle, v.4.4.3. The measuring precision was of $\pm 0.1^{\circ}$. Typically, hydrophobic surfaces show water static contact angles $>90^{\circ}$, while hydrophilic surfaces show water static contact angles $<90^{\circ}$ [44]. Measurements were 
performed in needles collected from 6 different trees. Each value was calculated as the mean from the optically left and right margins of the water droplet. Two to four measuring replicates were conducted over each needle. Needles were handled with caution to prevent epicuticular wax removal.

\subsection{Desiccation Experiments}

Two desiccation experiments were performed. In a first experiment, a modification of the "Falcon method", described in López-Pozo et al. (2019) [45], was used to compare the tolerance to severe dehydration in both needle types [45]. Briefly, approximately $120 \mathrm{mg}$ of needle pieces were desiccated at ca. $75 \%, 50 \%$ or $10 \%$ relative humidity $(\mathrm{RH})$. In the first experiment, the relative water content (RWC) was estimated at the beginning, after $48 \mathrm{~h}$ of desiccation and after $24 \mathrm{~h}$ of rehydration as:

$$
(\mathrm{FW}-\mathrm{DW}) /(\mathrm{TW}-\mathrm{DW}) \times 100
$$

with TW (turgor weight) corresponding with the weight measured at full turgor, FW the weight of samples at a given time during the treatment, and DW the dry weight of samples after $24 \mathrm{~h}$ at $70{ }^{\circ} \mathrm{C}$ in the oven. The maximal photochemical efficiency of PSII (Fv/Fm) was used as fitness estimator and measured at the beginning of the experiment, after desiccation and after rehydration treatments, and then expressed in percent as relative values to that of the control.

In a second experiment a detailed monitoring of water loss, during long dehydrations $(300 \mathrm{~h})$ under the two most contrasting conditions (75\% and $<10 \%$ RHs) was conducted in intact needles. Needle base was covered with Vaseline to prevent massive water loss from the abscission area and to evaluate, instead, desiccation kinetics through intact needle surfaces. Both WC and Fv/Fm were monitored during the long desiccation kinetic and expressed as percent of the control.

\subsection{Thermo-Tolerance Assessment}

Two separate experiments were conducted. To evaluate tolerance to extreme low temperature, needles collected in April (winter to spring transition) were subjected to $-10^{\circ} \mathrm{C}$ for $30 \mathrm{~min}$ and maximal photochemical efficiency of PSII (Fv/Fm) used as estimation of needle fitness. For this Fv / Fm values obtained immediately after the treatment and after $24 \mathrm{~h}$ of recovery $\left(+20^{\circ} \mathrm{C}\right.$ and darkness) were compared with control values (prior treatment). To evaluate tolerance to high temperatures, needles collected in September (end of summer) were subjected to $30,32,34,36,38,40,42,44,46,48$ or $50{ }^{\circ} \mathrm{C}$ for $30 \mathrm{~min}$ and $\mathrm{Fv} / \mathrm{Fm}$ checked immediately after the treatment and after $24 \mathrm{~h}$ of recovery. Five replicates per needle type were used per each treatment. For temperature treatments we followed the protocol described in [46].

\subsection{Statistical Analyses}

One-way ANOVA with Tukey test as post hoc, when necessary, was conducted to evaluate statistical differences among treatments and/or needle types after checking homoscedasticity. All tests were conducted with SPSS 2019 (IBM Corp.) and with an $\alpha=0.05$.

\section{Results}

\subsection{Morpho-Anatomical Features of Needles}

Morphological and anatomical study of $P$. canariensis needle pairs taken from the same resprouting twigs of adult (60-70 y old) trees, led us to identify and quantify main differences between primary and secondary needles. Some of them were already apparent to the bare eye (Figure 1). Thus, the organization in single needles in macroblasts (primary) vs. three needles per brachyblast (secondary), the longer internode length among needle insertion/brachyblasts in the twig, the shorter leaf length and the wider leaf width, were all statistically significant between primary and secondary needles (Table 1). Unexpectedly, LMA did not differ significantly between needle types although was lower in primary 
needles (Figure 2, Table 1). Interestingly, primary needles had much lower stomatal density in the abaxial side compared to secondary needles (Figures 2 and 3, Table 1). Their bluish color agreed with a significantly thicker cuticle (almost 2-fold), and hydrophobicity (higher contact angle) when compared to secondary needles (Figure 1, Table 1). Major intratissular differences included (i) smaller structural fraction (e.g., \% of hypodermis, endodermis and vascular tissue to cross-section area), (ii) higher fraction of spongy parenchyma, (iii) higher cell diameter in dermal tissues and (iv) wider resin ducts, in primary needles (Figures 2-4 and Table 2). Frequency distribution of tracheid diameter followed a similar pattern in both needle types with tracheids of $3-4 \mu \mathrm{m} \varnothing$ being responsible for ca. $50 \%$ of the total conductive area (Figure S1).

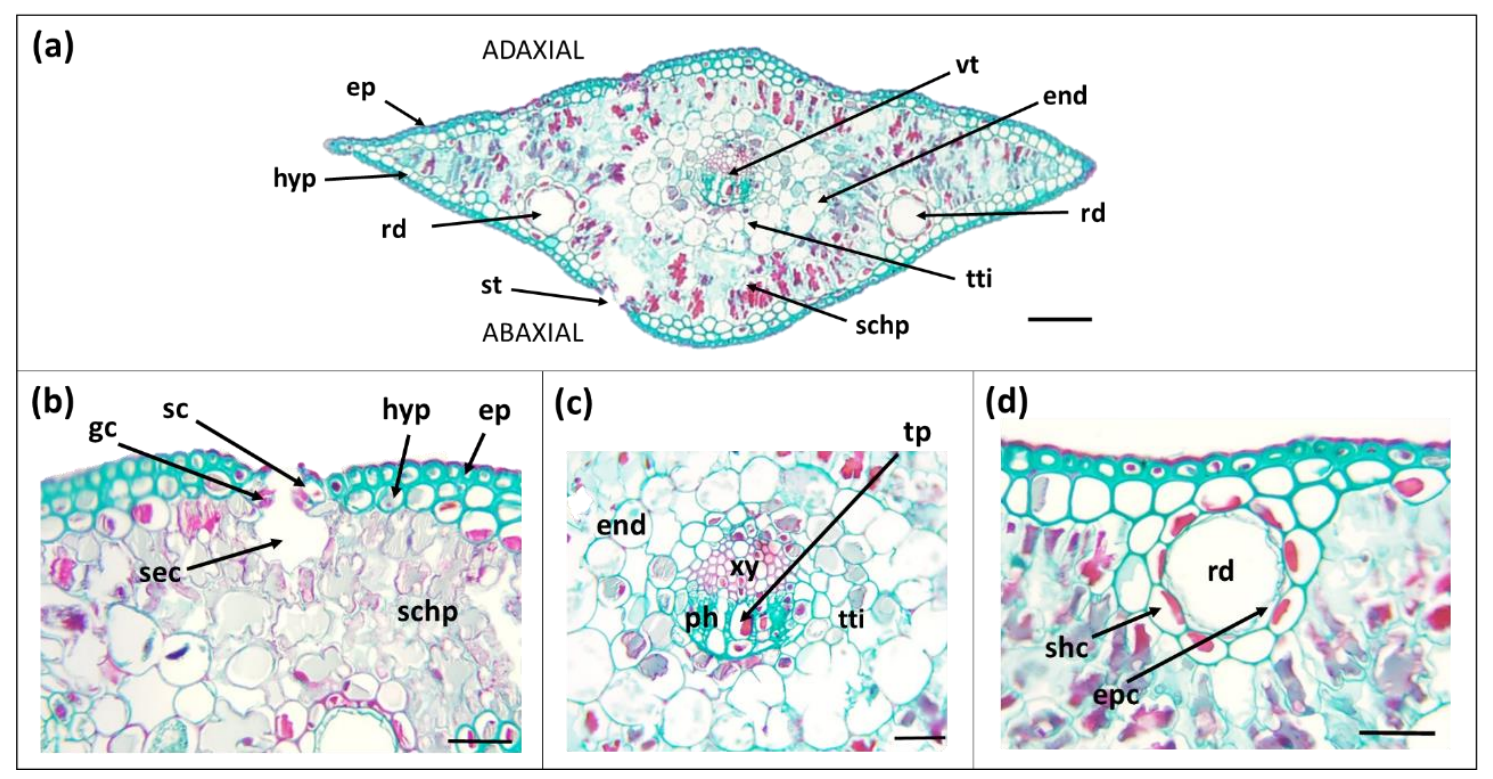

Figure 4. Stained cross-sections of Pinus canariensis primary (juvenile) needles. (a) Whole view of the needle cross-section. (b) Detail of the stomata and outer tissues of the needle. (c) Detail of the vascular bundle and all the conductive elements. (d) Detail of a resin duct. Abbreviations: end, endodermis; ep, epidermis; epc, epithelial cells; gc, guard cells; hyp, hypodermis; ph, phloem; rd, resin duct; sc, subsidiary cells; schp, spongy chlorophyll parenchyma; sec, substomatal chamber; shc, sheath cell; st, stomata; $\mathrm{tp}$, transfusion parenchyma; $\mathrm{tt}$, transfusion tracheid; $\mathrm{tti}$, transfusion tissue; $\mathrm{vt}$, vascular tissue; xy, xylem. Scale bars (a), $50 \mu \mathrm{m},(\mathbf{b}-\mathbf{d}), 20 \mu \mathrm{m}$. Safranin—fast green staining.

\subsection{Photochemistry and Gas Exchange}

Rapid Light Curves analysis showed different behaviour between needle type and season (Figure 5a). The highest maximum ETR $\left(\right.$ ETR $\left._{\max }\right)$ was obtained in secondary needles in autumn, reaching $90 \mu \mathrm{mol} \mathrm{m}{ }^{-2} \mathrm{~s}^{-1}$ while, on the contrary, primary needles in summer showed the lowest ETR $\mathrm{max}_{\text {ax }}$ values $\left(57 \mu \mathrm{mol} \mathrm{m} \mathrm{m}^{-2} \mathrm{~s}^{-1}\right.$, Figure $\left.5 \mathrm{~b}\right)$. Similar modulation was detected in the maximum PPFD at which the maximum ETR is maintained (PPFD sat) and the minimum absorbed saturating photosynthetic photon flux density (EK), showing the highest values in secondary needle in autumn $\left(733 \mu \mathrm{mol} \mathrm{m}^{-2} \mathrm{~s}^{-1}\right.$ and $318 \mu \mathrm{mol} \mathrm{m}{ }^{-2} \mathrm{~s}^{-1}$, respectively) and the lowest values in summer $\left(424 \mu \mathrm{mol} \mathrm{m}{ }^{-2} \mathrm{~s}^{-1}\right.$ and $184 \mu \mathrm{mol} \mathrm{m}{ }^{-2} \mathrm{~s}^{-1}$, respectively) (Figure $5 \mathrm{c}, \mathrm{e}$ ). No differences between needle types were observed in summer (Figure 5c,e). Finally, the apparent quantum efficiency (AQE) values did not show significant differences between needle types in autumn but these were observed in summer reaching the highest values the secondary needles (Figure $5 \mathrm{~d}$ ). Despite of being photochemically more efficient, secondary needles contained lower content of chlorophyll (Chl) as expressed per needle-projected area (Figure 6a). This difference was constant along the year. No significant differences were obtained between needle types in the ratios $\mathrm{Chla} / \mathrm{b}$ or Carotenoids/Chl even if considering different daytime and seasonal samplings (Figure 6b,c). 


\begin{tabular}{|ll|}
\hline Needle type & Season \\
$\begin{array}{l}\text { Secondary } \\
\text { Primary }\end{array}$ & Summer \\
Secondary & Autumn \\
Primary & \\
\hline
\end{tabular}

(b)

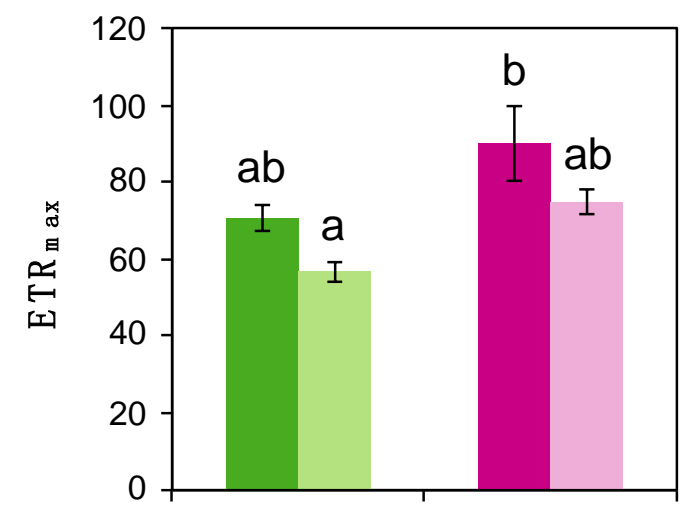

(d)

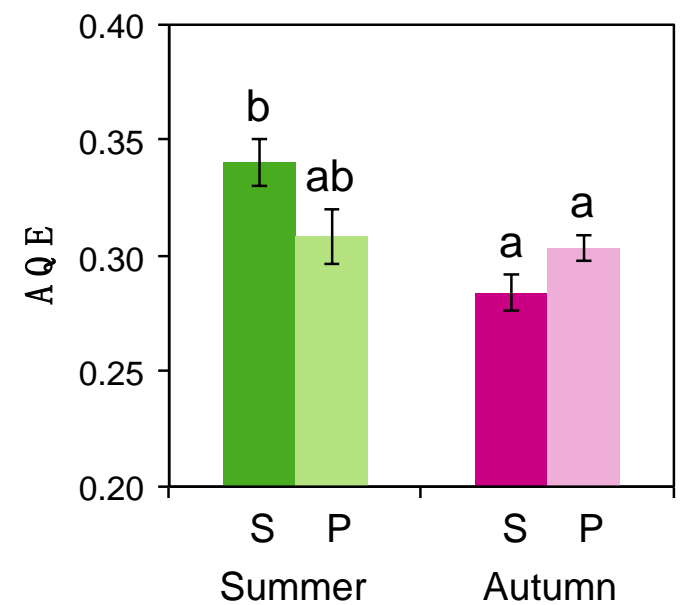

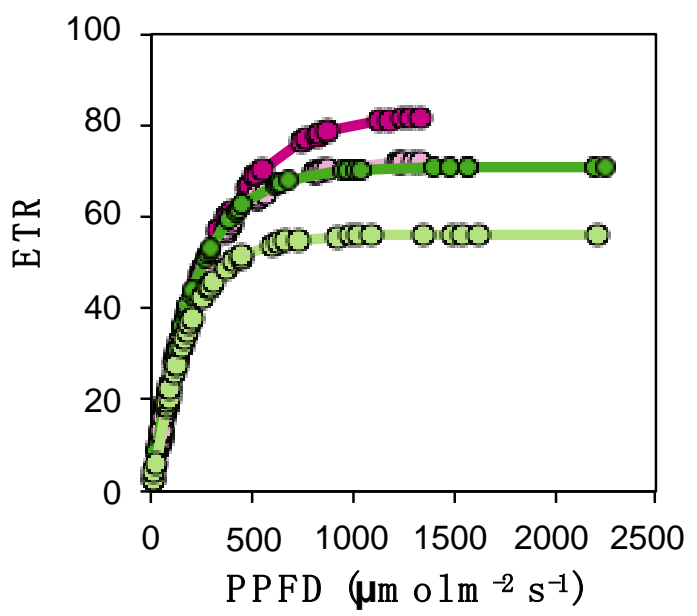

(a)

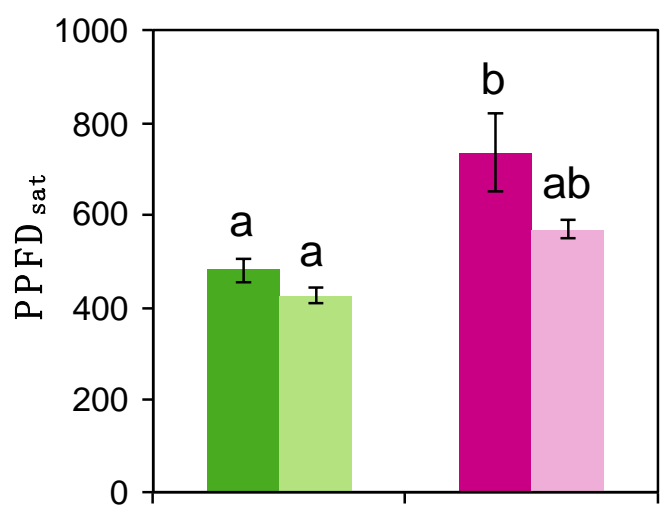

(c)

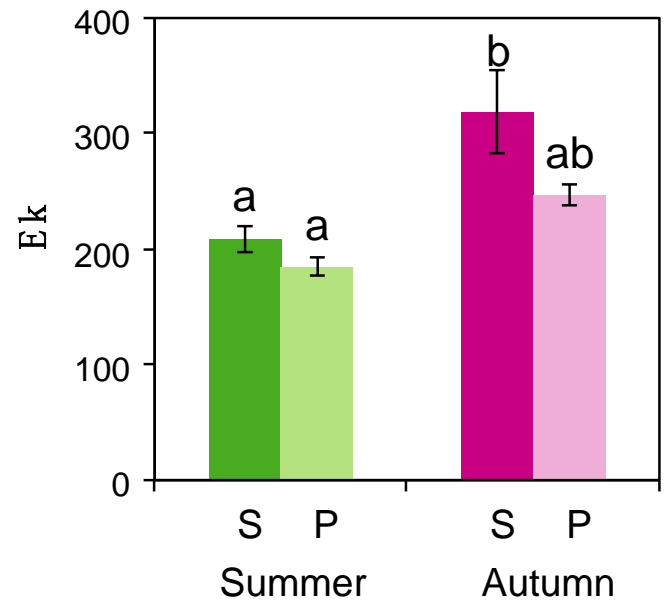

(e)

Figure 5. Rapid Light Curves and derived parameters as estimated through chlorophyll fluorescence analyses, of P. canariensis needles. (a) Light curves showing electron transport rate (ETR, in $\mu \mathrm{mol}$ electrons $\mathrm{m}^{-2} \mathrm{~s}^{-1}$ ) achieved by the needles at each photosynthetic photon flux density (PPFD, in $\mu \mathrm{mol}$ photons $\mathrm{m}^{-2} \mathrm{~s}^{-1}$ ). (b) Maximum electron transport rate (ETR max $)$ expressed in $\mu \mathrm{mol}$ electrons $\mathrm{m}^{-2} \mathrm{~s}^{-1}$. (c) Maximum PPFD at which the maximum ETR is maintained (PPFD sat $_{\text {) }}$ expressed in $\mu \mathrm{mol}$ photons $\mathrm{m}^{-2} \mathrm{~s}^{-1}$. (d) Apparent quantum efficiency (AQE) expressed in $\mu \mathrm{mol}$ photons used for photochemical processes per $\mu \mathrm{mol}$ photons absorbed by PSII. (e) Minimum saturating irradiance (Ek) $\mu \mathrm{mol}$ photons $\mathrm{m}^{-2} \mathrm{~s}^{-1}$. Data are mean \pm SE $(n=4)$. Different letters above bars depict significant differences among needle types and seasons $(p<0.05)$. See Section 2.3 of the Materials and Methods for details on how the parameters shown in panels (b-d) were estimated. 

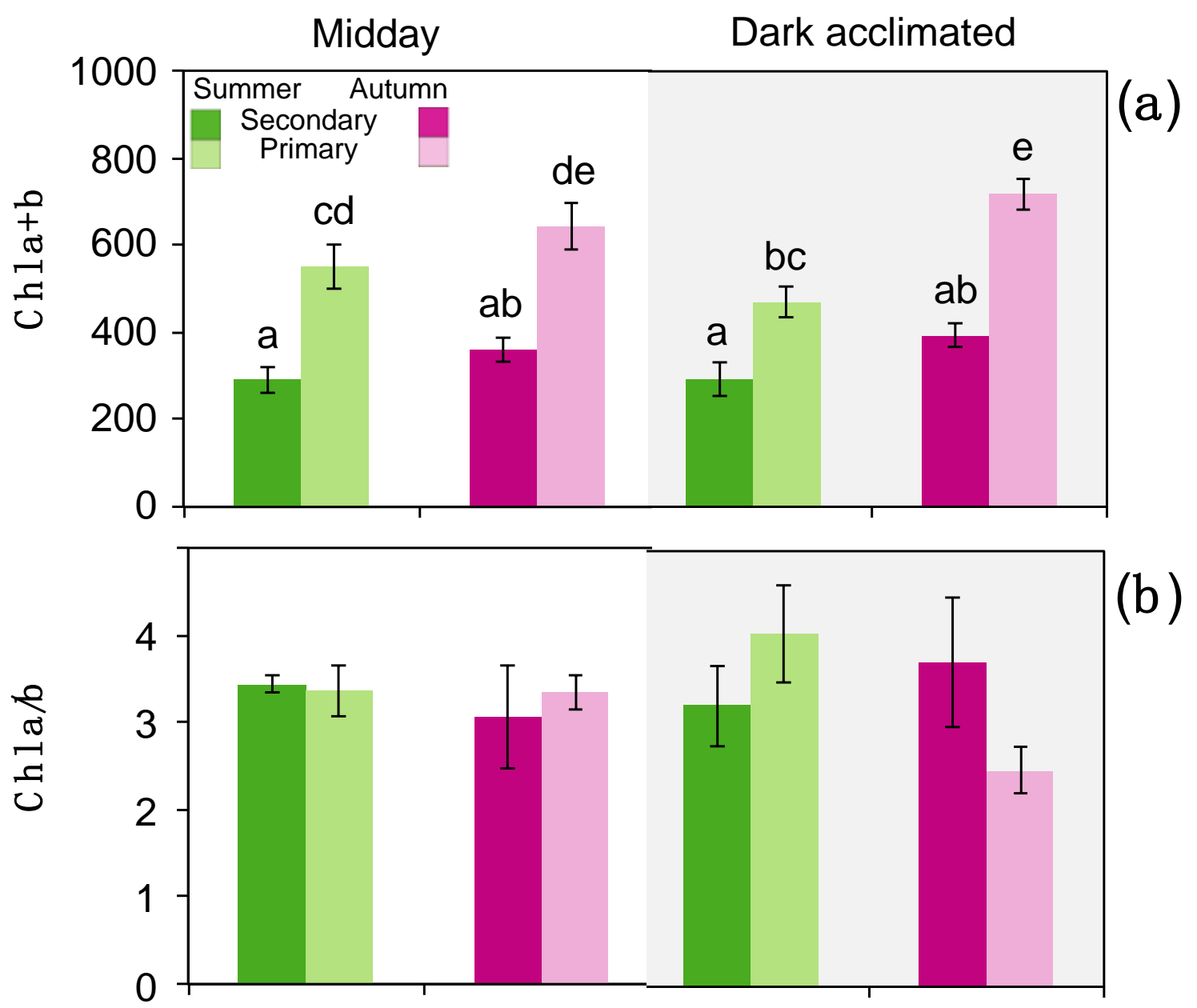

(b)

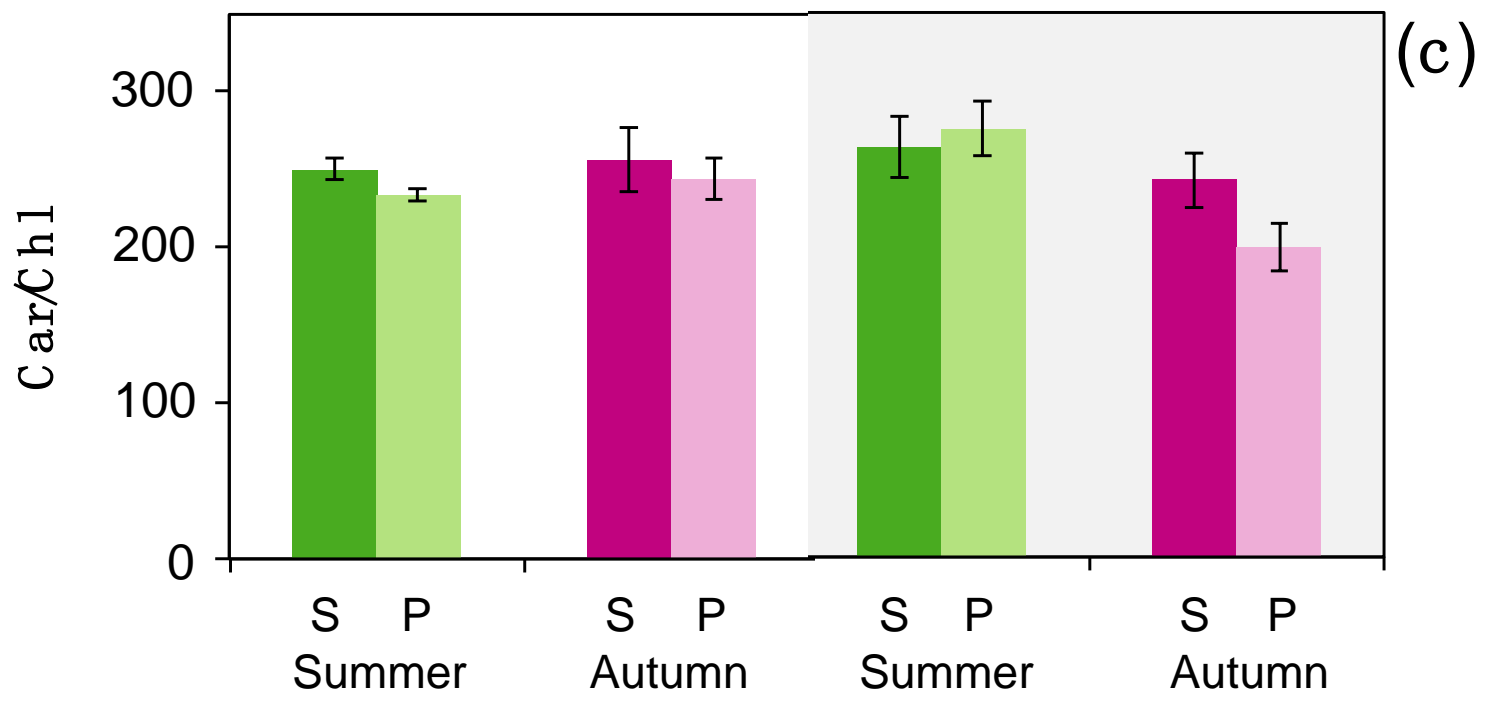

Figure 6. Photosynthetic pigment composition of $P$. canariensis needles as measured in the field at midday, or after $16 \mathrm{~h}$ of dark acclimation (at $\approx+20^{\circ} \mathrm{C}$ ). (a) Total chlorophyll content in $\mu \mathrm{mol} \mathrm{m}{ }^{-2}$. (b) Ratio of Chl $a$ to $b$ in $\mathrm{mol} \mathrm{mol}^{-1}$. (c) Total carotenoids content per chlorophyll in $\mathrm{mmol} \mathrm{mol}^{-1}$. Data are mean $\pm \mathrm{SE}(n=5)$. When significant, differences among needle types, daytime and seasons are depicted with different letters above the bars $(p<0.05)$. No significant differences among needle types, daytime or seasons were found for Chla/b ratio (b) nor for Car/Chl ratio (c).

Gas exchange results are shown in Figure 7. Contrary to our expectations, net carbon assimilation of primary and secondary needles of $P$. canariensis did not differ significantly, even if primary needles showed slightly lower values (i.e., $1.8 \pm 0.5$ in primary vs. 
$3.5 \pm 0.6 \mu \mathrm{mol} \mathrm{CO} \mathrm{m}^{-2} \mathrm{~s}^{-1}$ in secondary needles, in summer; $7.3 \pm 2.4$ vs. $9.5 \pm 1.2$, in autumn) (Figure 7). This pattern was actually maintained across seasons, and secondary needles showed lower values than primary needles again in autumn, after the rainfalls had already reactivated photosynthetical activity (Figure 7a). A similar behaviour was observed in the stomatal conductance. Lowest values of $0.066 \pm 0.007 \mathrm{~mol} \mathrm{H}_{2} \mathrm{O} \mathrm{m}^{-2} \mathrm{~s}^{-1}$ were obtained for primary needles in summer, and highest values of $0.095 \pm 0.030 \mathrm{~mol}$ $\mathrm{H}_{2} \mathrm{O} \mathrm{m}^{-2} \mathrm{~s}^{-1}$ were obtained for secondary needles in autumn (Figure $7 \mathrm{~b}$ ).

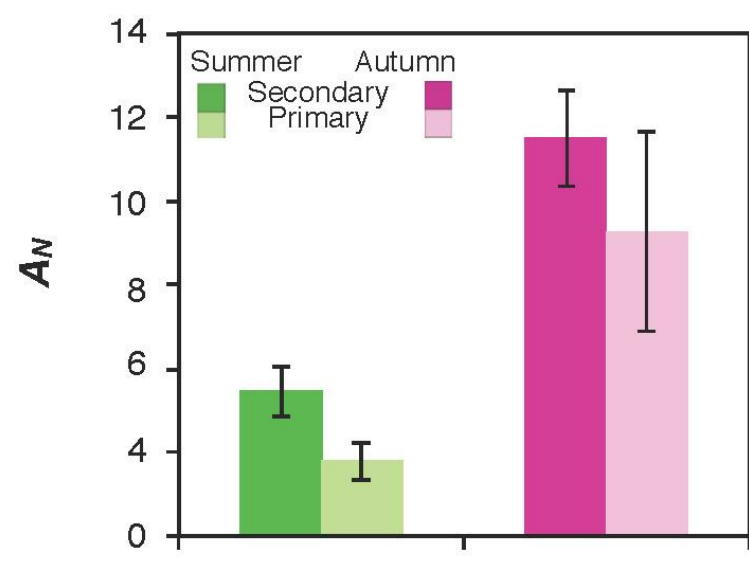

(a)

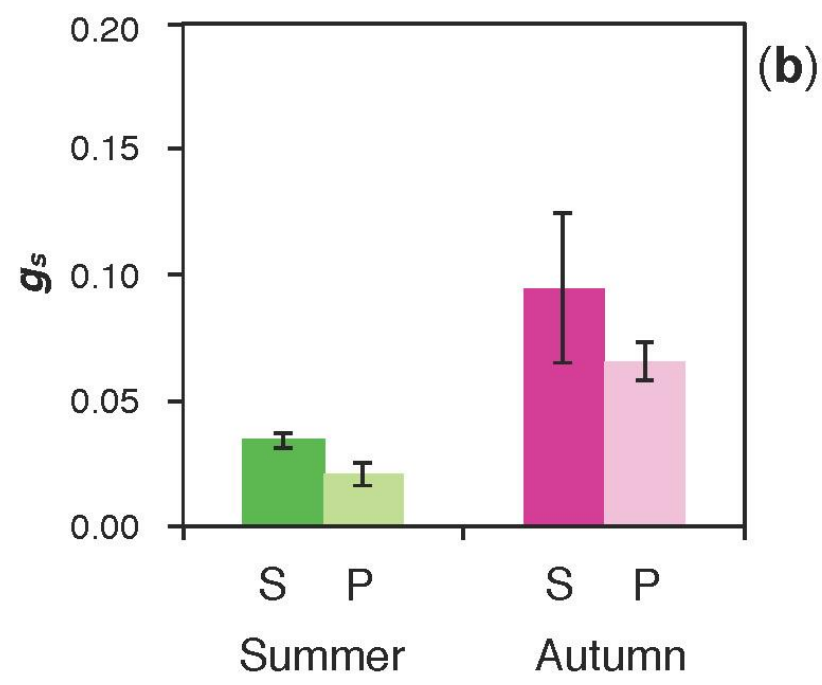

Figure 7. Gas exchange parameters measured in intact needles in the field and under natural conditions. (a) Net carbon assimilation $\left(A_{N}\right)$ in $\mu \mathrm{mol} \mathrm{CO} \mathrm{m}^{-2} \mathrm{~s}^{-1}$. (b) Stomatal conductance $\left(g_{s}\right)$ in $\mathrm{mol} \mathrm{H}_{2} \mathrm{O} \mathrm{m}^{-2} \mathrm{~s}^{-1}$. Data are mean $\pm \mathrm{SE}(n=3-5)$. No significant differences were found between needle types.

\subsection{Tolerance to Desiccation and Dehydration Kinetics}

The "Falcon test" concluded that none of the needle types was tolerant to desiccation, i.e., none of the samples that dehydrated below $30 \%$ RWC were able to recover $\geq 75 \%$ of initial Fv / Fm values (Figure S2). Interestingly, in all desiccating conditions, primary needles reached significantly lower RWCs than secondary needles (Figure S2). The results, of a second experiment, where the loss of water (dehydration kinetic) was carefully monitored under $<10 \%$ and $75 \%$ RH conditions is shown in Figure 8 . Notably, secondary needles were much more slower loosing water even if tremendously low $\mathrm{RH}<10 \%$ was used (Figure 8b). 


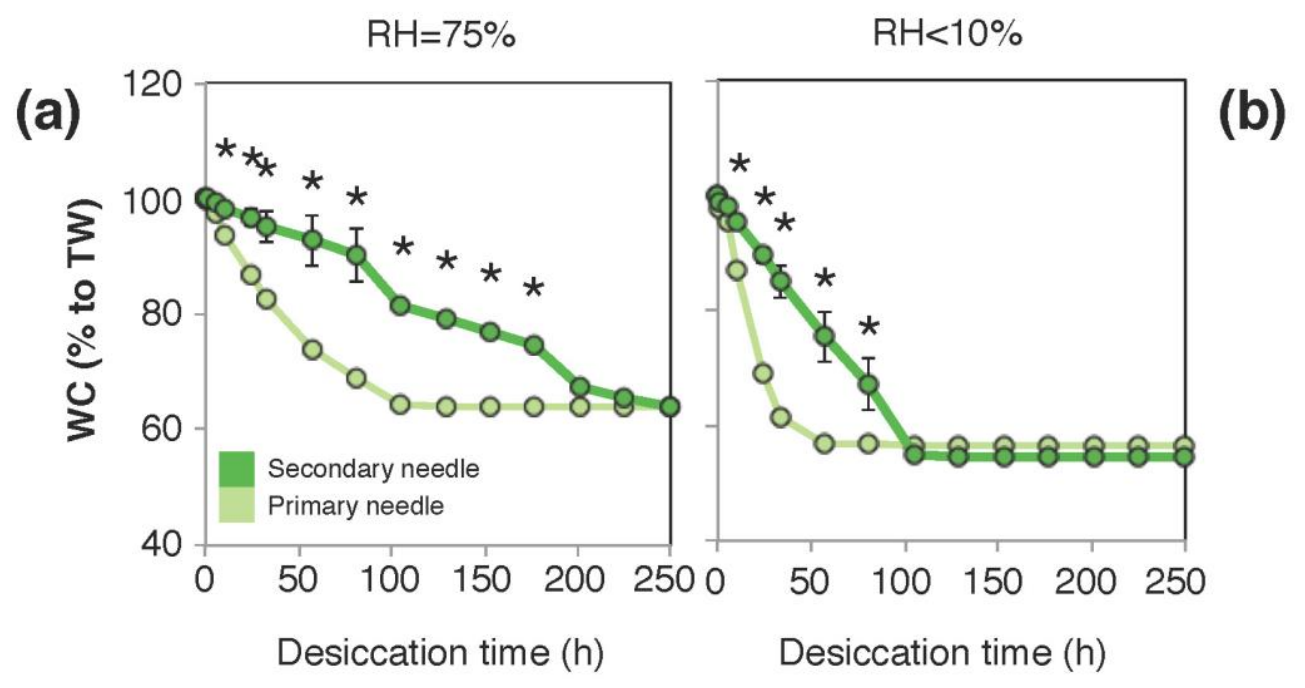

Figure 8. Loss of water in P. canariensis needles monitored during controlled desiccation and estimated through changes in water content (WC). The WC is expressed as fresh weight to turgor weight ratio in \%. (a) Dehydration conducted at $75 \% \mathrm{RH}$. (b) Dehydration conducted at $<10 \%$ RH. Secondary needles are depicted in dark green, primary needles in light green color. Data are mean $\pm \mathrm{SE}(n=6)$. Asterisks depict significant differences between changes in water content at certain desiccation time $(p<0.05)$.

\subsection{Tolerance to Extreme Temperatures}

When P. canariensis needles were subjected to low temperatures of $-10^{\circ} \mathrm{C}$ for $30 \mathrm{~min}$, no significant differences were obtained in the maximal photochemical efficiency of PSII (Fv/Fm) (Table 3). The Fv/Fm decreased slightly but not significantly in both needle types that keep comparable values. More marked differences between needles were obtained upon high-temperature treatments (Figure 9). Overall, both needles started a decrease in $\mathrm{Fv} / \mathrm{Fm}$ at temperatures higher than $40^{\circ} \mathrm{C}$. This depression, however, was more reliable when evaluated $24 \mathrm{~h}$ after the treatment (when irreparable damage to the leaf can be more accurately estimated) (Figure 9b). In these conditions, primary needles showed higher tolerance to +44 and $+46^{\circ} \mathrm{C}$ treatments.

Table 3. Effects of freezing assay $\left(-10^{\circ} \mathrm{C}\right.$ during $\left.30 \mathrm{~min}\right)$ on the $\mathrm{Fv} / \mathrm{Fm}$ of secondary and primary needles. Values are the average $\pm \mathrm{SE}(n=9)$. Non-significant differences between secondary and primary needles were found after one-way ANOVA $(p<0.05)$. Corresponding $F$ and $p$ values are shown in italics.

\begin{tabular}{cccc}
\hline \multirow{2}{*}{ Needle Age } & \multicolumn{3}{c}{ Fv/Fm Freezing Treatment $\left(-\mathbf{1 0}{ }^{\circ} \mathbf{C}\right)$} \\
\cline { 2 - 4 } & Initial & Post-Treatment & 24 h Recovery Post-Treatment \\
\hline Secondary & $0.763 \pm 0.010$ & $0.744 \pm 0.014$ & $0.743 \pm 0.013$ \\
Primary & $0.785 \pm 0.006$ & $0.771 \pm 0.007$ & $0.765 \pm 0.008$ \\
$F$ & 3.59 & 3.00 & 2.15 \\
$p$ & 0.076 & 0.103 & 0.162 \\
\hline
\end{tabular}




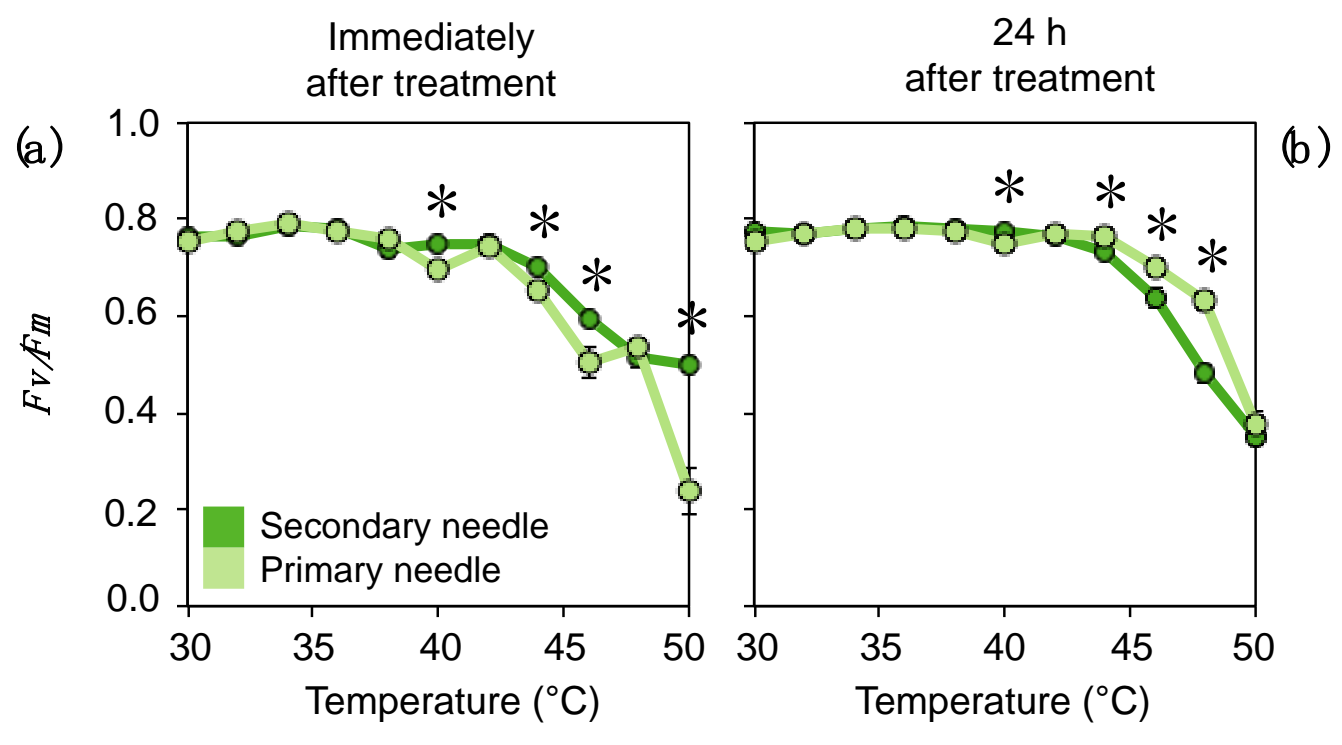

Figure 9. High temperature effects on P. canariensis needles, estimated through values of maximal photochemical efficiency of PSII (Fv/Fm). (a) Measured immediately after heat treatments. (b) Measurements $24 \mathrm{~h}$ after the treatment (needles incubated at $+20^{\circ} \mathrm{C}$ in darkness). Data are mean $\pm \mathrm{SE}(n=5)$. Asterisks depict significant differences between needle types at certain temperature treatments $(p<0.05)$. No statistical differences were found in the absolute water content between needle types used for this experiment: primary needles had $1.43 \pm 0.04 \mathrm{gH}_{2} \mathrm{O} \mathrm{g}^{-1} \mathrm{DW}$ and secondary needles $1.63 \pm 0.05 \mathrm{gH}_{2} \mathrm{O} \mathrm{g}^{-1} \mathrm{DW}$ (mean $\left.\pm \mathrm{SE}, n=15\right)$.

\section{Discussion}

\subsection{Study Frame}

Leaf anatomy and function are strongly related. "Leaf economics spectrum" theory offers a solid framework to this fact across environments and species with just a couple of exceptions escaping to it $[47,48]$. On the other hand, both organ (leaf) and individual (tree) age can strongly affect the metabolic activity (e.g., tocopherol content rises with leaf-age [49]) and the reallocation of resources that will end in different structural traits. As an example, a recent work by Azuma et al. (2019), revealed significant differences in needle LMA of mature (ca. 100 years) vs. old (ca. 300 years) trees of $P$. densiflora [50] despite comparable photosynthetic capacity around $5 \mu \mathrm{mol} \mathrm{CO} \mathrm{m}^{-2} \mathrm{~s}^{-1}$. Thus, typically, anatomical, environmental and ontogenic factors overlap, making it difficult to disentangle the reasons behind differential physiology across needles. While leaf-heteroblasty may represent one of the most extreme evidences regarding anatomical divergence within a single plant, most often, different leaf types will occupy different environments (e.g., understorey vs. canopy in seedling vs. adult trees) [2]. Here, we present a quite unique and promising case study in which two needle types, ontogenically-driven, co-habit in the same microenvironment and sprout almost contemporarily from the same adult tree: ca. 70 years individuals of $P$. canariensis; primary and secondary needles from resprouting twigs (Figure 1).

\subsection{Anatomical and Physiological Traits Related to Photosynthesis}

By comparing needles from five different Pinus species, Wang et al. (2019), have recently concluded that needle size in pines is related to anatomical traits in a way that reflects the mechanical and physiological properties of the needle [51]. Thus, longer needles, generally encounter a trade-off between the relative fractions of support and photosynthetic tissue across Pinus species [51]. Secondary needles of P. canariensis evaluated in our study were significantly longer than their contemporary primary needles (Figure 1, Table 1). Accordingly, their intra-leaf tissue showed higher proportion of mechanically supporting tissue. Despite showing a much higher proportion of "mechanical tissue fraction" (e.g., ratio of the sum of epidermal tissues and xylem areas to needle cross-sectional area as 
in [51]), and higher conductive area per needle cross section (Table 2), secondary needles of $P$. canariensis, showed similar LMA, and $A_{N}$ values than primary needles (Figure 7). The obtained values of net carbon assimilation of 2-11 $\mu \mathrm{mol} \mathrm{CO} \mathrm{CO}^{-2} \mathrm{~s}^{-1}$ fall within the expected range for this species and habitat. As an example, data obtained in the same arid tree-line ecotone at Teide Mountain and covering a whole year and a wide variety of physiological conditions (including drought episodes) ranged between -1 and $+18 \mu \mathrm{mol} \mathrm{CO} \mathrm{Cm}^{-2} \mathrm{~s}^{-1}$ [52]. We did not find significant differences in $A_{N}$ between primary and secondary needles. This agrees with previous studies on P. halepensis, P. nigra, and P. pinea, provided both needle types have the same age [53], as was also our case. The LMA values obtained in our study, are also comparable to other Mediterranean pines [7]. We did not find significant differences in LMA between primary and secondary needles. This, contrasts with data from other species of Mediterranean Pinus, in which primary needles typically show lower LMA [7]. However, in that study is noteworthy that primary needles of seedlings were compared with secondary needles of adult trees. This differs with our case-study in which we compare coexisting primary and secondary needles in the same twig of adult trees.

Both needle types had a comparable thickness, but secondary needles had a significantly thinner cuticle (Tables 1 and 2). This, together with their higher stomatal density (on abaxial surface) very likely facilitates $\mathrm{CO}_{2}$ diffusion into secondary needles (Table 2). In accordance, secondary needles tended to have higher $\mathrm{ETR}_{\max }, A_{N}$ and $\mathrm{g}_{\mathrm{s}}$ than primary needles. Primary needles had higher $\mathrm{Chl} a+b$ content (Figure 6), which agreed with their higher proportion of photosynthetic tissue per leaf-cross-section area (Figure 2). The content of photosynthetic pigments can change in response to internal and external factors affecting the plants [54]. At daily scale, $\mathrm{Chl} \mathrm{a/b}$ and $\mathrm{Chl} \mathrm{a}+\mathrm{b}$ can oscillate in following endogenous circadian rhythms under controlled conditions in some species [55] and around summer solstice in P. sylvestris growing in the arctic [56]. For P. canariensis Tausz et al. (2001) found significant rise in $\mathrm{Chl} a+b$ at noon, but this results were obtained in potted seedlings [57]. We did not observe such a pattern in P. canariensis wild adult trees (Figure 6). This resembles the lack of diurnal fluctuations in the content of pigments described by Porcar-Castell et al. (2012) for P. sylevestris [58]. Seasonally, Chl a+b can slightly decrease towards winter in conifers $[52,59,60]$ but generally remains constant between summer and autumn [61], as was also the case of P. canariensis in our study and in previous studies with this species [52]. Overall, higher photochemical efficiency but lower Chl content were obtained in secondary needles of $P$. canariensis. Future analyses on traits affecting intratissular $\mathrm{CO}_{2}$ diffusion, such as cell-wall thickness and composition, and light use efficiency, such as chloroplast distribution and movements, or carotenoid composition etc. [7] would be interesting to deepen into the factors determining photosynthesis capacity and acclimation in the two needle types of $P$. canariensis.

\subsection{Water Relations and Stress Tolerance}

Both DW/FW ratio and water content at turgor were equal between secondary and primary needles in P. canariensis (Table 1), indicating a similar water holding capacity. Nevertheless, cuticle was almost two-fold thicker in primary needles, which were also less wettable, and had less stomatal density (Tables 1 and 2). The wettability of primary needles was strongly dependent on the presence of epicuticular waxes, which were easily removed upon manipulation, and we found a trend from less wettable base towards more wettable tip of the needle (data not shown). Wettability loss in parallel to loss of epicuticular waxes was already reported for P. sylvestris by Cape, 1983 [62]. More wettable surface at the tip than at the base of $P$. radiata needle could be related to wax composition and with higher weathering [63]. On the light of these anatomical and physical properties we would have expected a strong resistance against leaf dehydration. Nevertheless, both the "Falcon test" and the "Desiccation kinetic" experiments revealed a much slower water loss of secondary needles over the time (Figure 8 ). Secondary needles of P. canariensis have a very particular stomatal anatomy, different to any other pine, with 16 cells including uniquely 
shaped polar cells that form a cover above the epistomatal chamber [26]. This features have been related with an extreme adaptation to harsh environmental conditions [26]. These morphological adaptations, together with the different structure and chemistry of epicuticular waxes that differ both needle types [28], may be the reason why secondary needles are much more efficient than primary needles preventing water loss (Figure 8). This higher efficiency under dehydrating conditions of secondary needles is in agreement with experiments comparing seedlings of $P$. canariensis with both needle types developed under very arid conditions [17]. Drought experiments under controlled conditions have shown increasing LMA and decreasing $A_{N}$ in seedlings of some conifers [64] and a reduced leaf/area ratio in seedlings of $P$. canariensis, in which interaction with irradiance conditions was markedly relevant, i.e., more drastic effects of drought were obtained in a shade environment [65]. However, none of these studies has compared physiological responses of primary vs. secondary needles, which could increase our current understanding about the influence that leaf anatomical differences have on the functioning of $P$. canariensis needles.

Previous studies have indicated that primary needles are more sensitive to frost damage than secondary needles in many pine species [30,31]. In agreement with data from seedlings of $P$. canariensis [30], we did not found such a difference in secondary and primary needles from adult trees (Table 3). This is in accordance with temperature ranges on the study-ecotone, where freezing temperatures are common during several months along the year including frequent episodes of $<-5^{\circ} \mathrm{C}$ [52]. This species seems to suitably acclimate to freezing during winter conditions; it shows a slight down-regulation of photochemical efficiency and a rearrangement of photosynthetic pigment composition that successfully prevents irreparable damage [52]. Interestingly, primary needles were more tolerant to moderately high temperatures $\left(43\right.$ to $47^{\circ} \mathrm{C}$ ) what could represent some advantages in low-density stands during resprouting, after fire.

\section{Conclusions}

Resprouting twigs with coexisting primary and secondary needles of $P$. canariensis offers a valuable case study to assess morpho-physiological trade-offs at leaf level. Under the conditions of this study, set in a semi-arid treeline, primary needles had higher fraction of photosynthetic parenchyma and lower fraction of water conducting (xylem) and mechanical tissue (xylem plus epidermal tissues), similar net carbon assimilation, slightly better tolerance to heat and lower water retention capacity than secondary needles. Considering that $P$. canariensis is a fire-resistant and resprouting species, we conclude that primary needles enhance the possibilities of physiological response against some environmental cues in resprouting twigs. These advantages could be particularly useful after a fire in a strongly defoliated tree, and they are probably less evident in an understorey environment.

Supplementary Materials: The following are available online at https://www.mdpi.com/1999 $-4907 / 12 / 3 / 341 / s 1$, Figure S1: Frequency distribution of tracheid diameters according to their contribution to total conductive area obtained from primary and secondary needle cross-sections of P. canariensis, Figure S2: Relative water content (RWC) and maximal photochemical efficiency of PSII (Fv/Fm) of P. canariensis needles, obtained in the "Falcon Test". Table S1: Numbers of replicates and dates of collection for all samples used in this study.

Author Contributions: Conceptualization, B.F.-M.; methodology, M.A.R.-M., J.C.M., Á.M.G.-R. and B.F.-M.; formal analysis, M.A.R.-M., J.C.M., Á.M.G.-R. and B.F.-M.; data curation, B.F.-M. and Á.M.G.R.; writing—original draft preparation, B.F.-M. and M.A.R.-M.; writing—review and editing, B.F.-M., M.A.R.-M., J.C.M. and Á.M.G.-R. All authors have read and agreed to the published version of the manuscript.

Funding: J.C.M. was supported by the Ramon Areces Foundation (BEVP31A6157). B.F.-M. was granted with a ULL+MICIU research project (Ref. 1184_2020).

Institutional Review Board Statement: Not applicable.

Informed Consent Statement: Not applicable. 
Data Availability Statement: Data are available upon request to B.F.-M.

Acknowledgments: We thank Pável Brito Gutiérrez his assistance for LMA estimations, José Luis Vilas and Leire Ruiz for kindly lending their CA equipment, and managers of the Teide National Park for permission to work in the field.

Conflicts of Interest: The authors declare no conflict of interest.

\section{References}

1. Goebel, K. Ueber die Jugendzustände der Pflanzen. Flora 1889, 72, 1-44.

2. Zotz, G.; Wilhelm, K.; Becker, A. Heteroblasty-A review. Bot. Rev. 2011, 77, 109-151. [CrossRef]

3. Nakayama, H.; Sinha, N.R.; Kimura, S. How do plants and phytohormones accomplish heterophylly, leaf phenotypic plasticity, in response to environmental cues. Front. Plant Sci. 2017, 8, 1717. [CrossRef]

4. Nakayama, H.; Nakayama, N.; Nakamasu, A.; Sinha, N.; Kimura, S. Toward elucidating the mechanisms that regulate heterophylly. Plant Morphol. 2012, 24, 57-63. [CrossRef]

5. Gould, K. Leaf heteroblasty in Pseudopanax crassifolius: Functional signifciance of leaf morphology and anatomy. Ann. Bot. 1993, 71, 61-70. [CrossRef]

6. Climent, J.; San-Martín, R.; Chambel, M.R.; Mutke, S. Ontogenetic differentiation between Mediterranean and Eurasian pines (sect. Pinus) at the seedling stage. Trees Struct. Funct. 2011, 25, 175-186. [CrossRef]

7. Kuusk, V.; Niinemets, Ü.; Valladares, F. A major trade-off between structural and photosynthetic investments operative across plant and needle ages in three Mediterranean pines. Tree Physiol. 2018, 38, 543-547. [CrossRef]

8. Nowak-Dyjeta, K.; Giertych, M.J.; Thomas, P.; Iszkuło, G. Males and females of Juniperus communis L. and Taxus baccata L. show different seasonal patterns of nitrogen and carbon content in needles. Acta Physiol. Plant. 2017, 39, 191. [CrossRef]

9. Zhang, J.L.; Xu, X.H.; Li, X.G.; Li, Y.L.; Guy, R.D.; Chen, H.P. Photoprotection in heteromorphic leaves of savin juniper (Juniperus sabina L.). Photosynthetica 2019, 57, 780-787. [CrossRef]

10. Lin, J.; Jach, M.E.; Ceulemans, R. Stomatal density and needle anatomy of Scots pine (Pinus sylvestris) are affected by elevated $\mathrm{CO}_{2}$. New Phytol. 2001, 150, 665-674. [CrossRef]

11. Climent, J.; Dantas, A.K.; Alia, R.; Majada, J. Clonal variation for shoot ontogenetic heteroblasty in maritime pine (Pinus pinaster Ait.). Trees Struct. Funct. 2013, 27, 1813-1819. [CrossRef]

12. Fernández de Simón, B.; Sanz, M.; Cervera, M.T.; Pinto, E.; Aranda, I.; Cadahía, E. Leaf metabolic response to water deficit in Pinus pinaster Ait. relies upon ontogeny and genotype. Environ. Exp. Bot. 2017, 140, 41-55. [CrossRef]

13. Mediavilla, S.; Herranz, M.; González-Zurdo, P.; Escudero, A. Ontogenetic transition in leaf traits: A new cost associated with the increase in leaf longevity. J. Plant Ecol. 2014, 7, 567-575. [CrossRef]

14. Boddi, S.; Bonzi, L.M.; Calamassi, R. Structure and ultrastructure of Pinus halepensis primary needles. Flora 2002, 197, 10-23. [CrossRef]

15. Lester, D.T. Developmental patterns of axillary meristematic activity in seedlings of Pinus. Bot. Gaz. 1968, 129, 206-210. [CrossRef]

16. Calamassi, R.; Falusi, M.; Principe, M. Relations between apical structure and growth patterns in Pinus halepensis Mill. seedlings. G. Bot. Ital. 1988, 122, 321-338. [CrossRef]

17. Climent, J.; Chambel, M.R.; López, R.; Mutke, S.; Alía, R.; Gil, L. Population divergence for heteroblasty in the Canary Island pine (Pinus canariensis, Pinaceae). Am. J. Bot. 2006, 93, 840-848. [CrossRef] [PubMed]

18. Jiménez, M.S.; Zellnig, G.; Stabentheiner, E.; Peters, J.; Morales, D.; Grill, D. Structure and ultrastructure of Pinus canariensis needles. Flora 2000, 195, 228-235. [CrossRef]

19. Ferrer-Gallego, P.P.; Boisset, F. Correct type designation of the endemic Canary pine Pinus canariensis (Pinaceae). Taxon 2018, 67, 581-585. [CrossRef]

20. Climent, J.; Tapias, R.; Pardos, J.A.; Gil, L. Fire adaptations in the Canary Islands pine (Pinus canariensis). Plant Ecol. 2004, 171, 185-196. [CrossRef]

21. Brito, P.; Lorenzo, J.R.; González-Rodríguez, Á.M.; Morales, D.; Wieser, G.; Jimenez, M.S. Canopy transpiration of a Pinus canariensis forest at the tree line: Implications for its distribution under predicted climate warming. Eur. J. For. Res. 2014, 133, 491-500. [CrossRef]

22. del Arco Aguilar, M.J.; Rodríguez Delgado, O. Vegetation of the Canary Islands; Springer: Cham, Switzerland, 2018; ISBN 9783319772547.

23. Fernández-Palacios, J.M.; Nicolás, J.P. Altitudinal pattern of vegetation variation on Tenerife. J. Veg. Sci. 1995, 6, 183-190. [CrossRef]

24. Miranda, J.C.; Rodríguez-Calcerrada, J.; Pita, P.; Saurer, M.; Oleksyn, J.; Gil, L. Carbohydrate dynamics in a resprouting species after severe aboveground perturbations. Eur. J. For. Res. 2020, 139, 841-852. [CrossRef]

25. Brito, P.; Lorenzo, J.R.; González-Rodríguez, Á.M.; Morales, D.; Wieser, G.; Jiménez, M.S. Canopy transpiration of a semi arid Pinus canariensis forest at a treeline ecotone in two hydrologically contrasting years. Agric. For. Meteorol. 2015, 201, 120-127. [CrossRef]

26. Zellnig, G.; Peters, J.; Jiménez, M.S.; Morales, D.; Grill, D.; Perktold, A. Three-dimensional reconstruction of the stomatal complex in Pinus canariensis needles using serial sections. Plant Biol. 2002, 4, 70-76. [CrossRef] 
27. Grill, D.; Tausz, M.; Pöllinger, U.; Jiménez, M.; Morales, D. Effects of drought on needle anatomy of Pinus canariensis. Flora 2004, 199, 85-89. [CrossRef]

28. Stabentheiner, E.; Pfeifhofer, H.W.; Peters, J.; Jiménez, M.S.; Morales, D.; Grill, D. Different surface characteristics of primary and secondary needles of Pinus canariensis. Flora 2004, 199, 90-99. [CrossRef]

29. De Simón, B.F.; Cadahía, E.; Aranda, I. Metabolic response to elevated $\mathrm{CO}_{2}$ levels in Pinus pinaster Aiton needles in an ontogenetic and genotypic-dependent way. Plant Physiol. Biochem. 2018, 132, 202-212. [CrossRef] [PubMed]

30. Climent, J.; Silva, F.C.E.; Chambel, M.R.; Pardos, M.; Almeida, M.H. Freezing injury in primary and secondary needles of Mediterranean pine species of contrasting ecological niches. Ann. For. Sci. 2009, 66, 407. [CrossRef]

31. Pardos, M.; Climent, J.; Almeida, H.; Calama, R. The role of developmental stage in frost tolerance of Pinus pinea L. seedlings and saplings. Ann. For. Sci. 2014, 71, 551-562. [CrossRef]

32. Ruffault, J.; Curt, T.; Moron, V.; Trigo, R.M.; Mouillot, F.; Koutsias, N.; Pimont, F.; Martin-StPaul, N.; Barbero, R.; Dupuy, J.L.; et al. Increased likelihood of heat-induced large wildfires in the Mediterranean Basin. Sci. Rep. 2020, 10, 13790. [CrossRef]

33. Perry, J. The Pines of Mexico and Central America; Timber Press Inc.: Portland, OR, USA, 1991.

34. Burns, R.; Honkala, B. Silvics of North America. Vol 1. Agriculture Handbook (Washington); USDA Forest Service: Washington, DC, USA, 1990.

35. Genty, B.; Briantais, J.M.; Baker, N.R. The relationship between the quantum yield of photosynthetic electron transport and quenching of chlorophyll fluorescence. Biochim. Biophys. Acta Gen. Subj. 1989, 990, 87-92. [CrossRef]

36. White, A.J.; Critchley, C. Rapid light curves: A new fluorescence method to assess the state of the photosynthetic apparatus. Photosynth. Res. 1999, 59, 63-72. [CrossRef]

37. Murchie, E.H.; Lawson, T. Chlorophyll fluorescence analysis: A guide to good practice and understanding some new applications. J. Exp. Bot. 2013, 64, 3983-3998. [CrossRef]

38. Saroussi, S.; Beer, S. Alpha and quantum yield of aquatic plants derived from PAM fluorometry: Uses and misuses. Aquat. Bot. 2007, 86, 89-92. [CrossRef]

39. Ralph, P.J.; Gademann, R. Rapid light curves: A powerful tool to assess photosynthetic activity. Aquat. Bot. 2005, 82, 222-237. [CrossRef]

40. Niinemets, Ü.; Lukjanova, A.; Turnbull, M.H.; Sparrow, A.D. Plasticity in mesophyll volume fraction modulates light-acclimation in needle photosynthesis in two pines. Tree Physiol. 2007, 27, 1137-1151. [CrossRef]

41. Peters, J.; Morales, D.; Soledad Jiménez, M. Gas exchange characteristics of Pinus canariensis needles in a forest stand on Tenerife, Canary Islands. Trees Struct. Funct. 2003, 17, 492-500. [CrossRef]

42. Lichtenthaler, H.K. Chlorophylls and carotenoids: Pigments of photosyntehtic biomembranes. Methods Enzymol. 1987, 148, 350-382.

43. Fernández-Marín, B.; López-pozo, M.; Perera-castro, A.V.; Arzac, M.I.; Sáenz-ceniceros, A.; Colesie, C.; Ríos, A.D.L.; Sancho, L.G.; Pintado, A.; Laza, J.M. Symbiosis at its limits: Ecophysiological consequences of lichenization in the genus Prasiola in Antarctica. Ann. Bot. 2019, 124, 1211-1226. [CrossRef] [PubMed]

44. Hanson, D.T.; Rice, S.K. Photosynthesis in Bryophytes and Early Land Plants; Springer: Dordrecht, The Netherlands, 2014 ; Volume 37. [CrossRef]

45. López-Pozo, M.; Flexas, J.; Gulías, J.; Carriquí, M.; Nadal, M.; Perera-Castro, A.; Clemente-Moreno, M.; Gago, J.; Núñez-Olivera, E.; Martínez-Abaigar, J.; et al. A field portable method for semi-quantitative estimation of dehydration tolerance of photosynthetic tissues across distantly related land plants. Physiol. Plant. 2019, 167, 540-555. [CrossRef]

46. Perera-Castro, A.; Brito, P.; González-Rodríguez, A. Changes in thermic limits and acclimation assessment for an alpine plant by chlorophyll fluorescence analysis: Fv/Fm vs. Rfd. Photosynthetica 2018, 56, 527-536. [CrossRef]

47. Anderegg, L.D.; Berner, L.T.; Badgley, G.; Sethi, M.L.; Law, B.E.; HilleRisLambers, J. Within-species patterns challenge our understanding of the leaf economics spectrum. Ecol. Lett. 2018, 21, 734-744. [CrossRef] [PubMed]

48. Wright, I.J.; Reich, P.B.; Westoby, M.; Ackerly, D.D.; Baruch, Z.; Bongers, F.; Cavender-Bares, J.; Chapin, T.; Cornelissen, J.H.C.; Diemer, M.; et al. The worldwide leaf economics spectrum. Nature 2004, 428, 821-827. [CrossRef]

49. Lizarazo, K.; Fernández-Marín, B.; Becerril, J.M.; García-Plazaola, J.I. Ageing and irradiance enhance vitamin E content in green edible tissues from crop plants. J. Sci. Food Agric. 2010, 90, 1994-1999. [CrossRef] [PubMed]

50. Azuma, W.; Ishii, H.R.; Masaki, T. Height-related variations of leaf traits reflect strategies for maintaining photosynthetic and hydraulic homeostasis in mature and old Pinus densiflora trees. Oecologia 2019, 189, 317-328. [CrossRef] [PubMed]

51. Wang, N.; Palmroth, S.; Maier, C.A.; Domec, J.C.; Oren, R. Anatomical changes with needle length are correlated with leaf structural and physiological traits across five Pinus species. Plant Cell Environ. 2019, 42, 1690-1704. [CrossRef]

52. González-Rodríguez, Á.M.; Brito, P.; Lorenzo, J.R.; Jiménez, M.S. Photosynthetic performance in Pinus canariensis at semiarid treeline: Phenotype variability to cope with stressful environment. Forests 2019, 10, 845. [CrossRef]

53. Kuusk, V.; Niinemets, Ü.; Valladares, F. Structural controls on photosynthetic capacity through juvenile-to-adult transition and needle ageing in Mediterranean pines. Funct. Ecol. 2018, 32, 1479-1491. [CrossRef]

54. Esteban, R.; Barrutia, O.; Artetxe, U.; Fernández-Marín, B.; Hernández, A.; García-Plazaola, J.I. Internal and external factors affecting photosynthetic pigment composition in plants: A meta-analytical approach. New Phytol. 2015, 206, 268-280. [CrossRef]

55. García-Plazaola, J.I.; Fernández-Marín, B.; Ferrio, J.P.; Alday, J.G.; Hoch, G.; Landais, D.; Milcu, A.; Tissue, D.T.; Voltas, J.; Gessler, A.; et al. Endogenous circadian rhythms in pigment composition induce changes in photochemical efficiency in plant canopies. Plant Cell Environ. 2017, 40, 1153-1162. [CrossRef] [PubMed] 
56. Fernández-Marín, B.; Atherton, J.; Olascoaga, B.; Kolari, P.; Porcar-Castell, A.; García-Plazaola, J.I. When the sun never sets: Daily changes in pigment composition in three subarctic woody plants during the summer solstice. Trees Struct. Funct. 2018, 32, 615-630. [CrossRef]

57. Tausz, M.; Wonisch, A.; Peters, J.; Jiménez, M.S.; Morales, D.; Grill, D. Short-term changes in free radical scavengers and chloroplast pigments in Pinus canariensis needles as affected by mild drought stress. J. Plant Physiol. 2001, 158, 213-219. [CrossRef]

58. Porcar-Castell, A.; Garcia-Plazaola, J.I.; Nichol, C.J.; Kolari, P.; Olascoaga, B.; Kuusinen, N.; Fernández-Marín, B.; Pulkkinen, M.; Juurola, E.; Nikinmaa, E. Physiology of the seasonal relationship between the photochemical reflectance index and photosynthetic light use efficiency. Oecologia 2012, 170, 313-323. [CrossRef]

59. Morais, M.C.; Cabral, J.A.; Gonçalves, B. Seasonal variation in the leaf physiology of co-occurring invasive (Hakea sericea) and native (Pinus pinaster) woody species in a Mediterranean-type ecosystem. For. Ecol. Manag. 2021, 480, 118662. [CrossRef]

60. Sofronova, V.E.; Dymova, O.V.; Golovko, T.K.; Chepalov, V.A.; Petrov, K.A. Adaptive changes in pigment complex of Pinus sylvestris needles upon cold acclimation. Russ. J. Plant Physiol. 2016, 63, 433-442. [CrossRef]

61. Deligöz, A.; Bayar, E.; Genç, M.; Karatepe, Y.; Kirdar, E.; Cankara, F.G. Seasonal and needle age-related variationsin the biochemical characteristics of Pinus nigra subsp. pallasiana (Lamb.) Holmboe. J. For. Sci. 2018, 64, 379-386. [CrossRef]

62. Cape, J.N. Contact angles of water droplets on needles of Scots Pine (Pinus sylvestris) growing in polluted atmospheres. New Phytol. 1983, 93, 293-299. [CrossRef]

63. Leyton, L.; Armitage, I.P. Cuticle structure and water relations of the needles of Pinus radiata (D. Don). New Phytol. 1968, 67, 31-38. [CrossRef]

64. Bhusal, N.; Lee, M.; Reum Han, A.; Han, A.; Kim, H.S. Responses to drought stress in Prunus sargentii and Larix kaempferi seedlings using morphological and physiological parameters. For. Ecol. Manag. 2020, 465, 118099. [CrossRef]

65. Climent, J.M.; Aranda, I.; Alonso, J.; Pardos, J.A.; Gil, L. Developmental constraints limit the response of Canary Island pine seedlings to combined shade and drought. For. Ecol. Manag. 2006, 231, 164-168. [CrossRef] 